\title{
PUBLIC POLICY, ENTREPRENEURSHIP, AND VENTURE CAPITAL THE UNITED STATES*
}

\section{Journal of Corporate Finance, forthcoming}

\author{
Douglas Cumming \\ Professor and Ontario Research Chair \\ York University - Schulich School of Business \\ 4700 Keele Street \\ Toronto, Ontario M3J 1P3 \\ Canada \\ http://ssrn.com/author $=75390$ \\ douglas.cumming@gmail.com
}

\author{
Dan Li \\ The School of Economics and Finance \\ University of Hong Kong \\ 8th Floor Kennedy Town Centre \\ 23 Belcher's Street \\ Kennedy Town, \\ Hong Kong \\ $\underline{\text { http://ssrn.com/author=868088 }}$ \\ lidan@hku.hk
}

This draft: 23 April 2013

\begin{abstract}
* We are indebted Harold Mulherin, the Editor, and to an anonymous referee for very timely and helpful suggestions. Also, we are indebted to the Fraser Institute for data, assistance, suggestions and comments. We especially owe thanks to Amela Karabegovic, Alex Gainer, and Keith Godin. As well, for helpful comments we owe thanks to Ming Dong, Katrin Hussinger, Gordon Roberts and Pauline Shum, and the IFN Conference on the Economics of Ownership, Organization and Industrial Development in Vaxholm, Sweden (10-11 September 2009), York University (January 2010 and March 2011), the American Law and Economics Association, Princeton (May 2010), the University of Saskatchewan (May 2010), the Third Annual Searle Research Symposium on the Economics and Law of the Entrepreneur at Northwestern University (June 2010), the European Financial Management Association Annual Conference in Aarhus, Denmark (June 2010), the European Financial Management Association Meeting on Alternative Investments in Toronto (April 2011), the Milan VICO Conference (June 2011), the Conference on Business Creation at George Washington University (October 2011), and the Kauffmann Empirical Entrepreneurship Conference, Philadelphia (November 2011), and the Eastern Finance Association, Boston (April 2012).
\end{abstract}




\title{
Public Policy, ENTREPRENEURShip, AND VENTURE CAPITAL THE UNITED STATES
}

\begin{abstract}
This paper empirically examines business starts, deaths, venture capital and patents in relation to U.S. public policy. The most consistent evidence in the data shows that lower levels of labor frictions and higher levels of SBIR awards are associated with more business starts and higher levels of venture capital per population. Counter to expectations, the data indicate a positive impact from the homestead exemption only among the bottom quartile homestead exemption states, and otherwise a negative impact. We analyze a variety of other policy instruments and compare the effects of policy in regular times with the financial crisis of 20082010.
\end{abstract}

Keywords: Entrepreneurial Finance, Venture Capital, Public Policy, Tax, Labor Law, Bankruptcy, SBIR

JEL Codes: G24, G32, G33, G38, K22, K31, K35, L26 


\section{Introduction}

A central question in entrepreneurial finance is the appropriate role for public policy for stimulating investment, such as venture capital, and for stimulating the creation, survival, and innovation (Jeng and Wells, 2000; Denis, 2004). The stimulation of entrepreneurship can occur through direct government subsidy programs and legislative changes that affect the institutional setting. These programs are large and important around the world. For example, The World Bank spent more than \$US10 billion in 2001-2005 to promote small enterprises (Beck et al., 2008). In the U.S., government spending grew to over $45 \%$ of GDP during the recent financial crisis (Chantrill, 2009), a record level since WWII. The increasing presence of government in stimulating entrepreneurial activity gives rise to a growing need to reexamine the role of public policy on entrepreneurial activity and entrepreneurial finance. How exactly do public policy tool mechanisms such as government transfers, and labor and bankruptcy laws influence the rate of business start-up activity, venture capital finance, and innovation? How important are direct policy measures such as the Small Business Innovation Research (SBIR) Awards and business incubators relative to taxation and the institutional environment? What is the relative importance of the institutional setting versus direct policy instruments such as the SBIR program? How do such mechanisms compare in normal times versus the financial crisis period of 2008-2010?

In this paper we examine state level data over 1995-2010 to study the determinants of new establishment births, births - deaths, venture capital, and patents. Our main findings highlight strong and consistent evidence that lower levels of labor frictions and higher levels of SBIR awards are associated with more business starts and higher levels of venture capital per population. The data do not indicate much evidence consistent with the view that the overall tax burden gives rise economic harm in terms of less entrepreneurial activity. Counter to expectations, the data indicate a positive impact of the homestead exemption only among the bottom quartile homestead exemption states, and otherwise a negative impact. We analyze a variety of other policy instruments and compare the effects of policy in regular times with the financial crisis of 2008-2010.

Our paper is at a broad level related to recent scholarship such as Lerner (2009), who has argued that direct government investment programs often are poorly designed and hence fail to meet their objectives. Also, at a broad level our work is related to earlier work on the topic of 
venture capital fundraising which compares venture capital to GDP (Jeng and Wells, 2000), and this work highlights the importance of legal and institutional setting across countries for stimulating venture capital investment.

Our work is perhaps most closely related to scholarship that has examined differences in entrepreneurship across U.S. states. Earlier work on topic based on policy measures averaged over 1995-1999 and outcome measures average over 2000-2004 (Xue and Klein, 2010) suggests the importance of a smaller public sector for stimulating entrepreneurial activity, as measured by an aggregation of patents, SBIR awards, venture capital, and technology establishments. Our findings are consistent with Xue and Klein (2010), but in this paper, we take a somewhat different approach by examining a panel data setting, different outcome variables that are not aggregated such as new establishment births, births - deaths, venture capital, and patents, and examine data that includes but is not limited to the recent financial crisis.

This paper is organized as follows. The second section describes policy instruments that potentially impact on entrepreneurial activity, venture capital, and innovation. The third section introduces the data and provides summary statistics. Multivariate regression analyses are thereafter presented in the fourth section. After the presentation of the main regressions, we discuss alternative robustness checks, acknowledge limitations, and consider extensions. Concluding remarks follow in the last section.

\section{Policy Instruments for Entrepreneurship, Venture Capital, and Innovation}

The OECD (1996) and others have argued that entrepreneurship and innovation will facilitate economic growth and the competitive advantage of nations in the 21st century. Much evidence, albeit not all, indicates small high-tech companies contribute disproportionately to innovation and economic growth (the World Bank, 1994, 2002, 2004). Drivers of entrepreneurial activity have been extensively researched in the U.S. and internationally. Empirical evidence points to a number of factors, including market conditions, education, finance, information, spillovers and agglomeration (Audretsch, 2007; Audretsch and Feldman, 1996; Audretsch and Keilbach, 2007; Colombo and Grilli, 2008; Bertoni et al., 2011; Fossen, 2012; Gaston and Nelson, 2000; Imai and Kawagoe, 2000; Wang and Wang, 2010, 2012a,b; Wang and Zhou, 2004). Empirical evidence has likewise confirmed the role of personal bankruptcy laws to mitigate the cost of failure (Fan and White, 2003; Berkowitz and White, 2004, Armour and 
Cumming, 2008), taxation to minimize moral hazard and maximize the returns to entrepreneurship, and legal and institutional settings that protect property rights and mitigate the start-up costs and costs of failure (La Porta et al., 1999; Djankov et al., 2002; Glasear et al., 2004; Acemoglu and Johnson, 2005; Levine, 2005; Klapper et al., 2006; Engel and Keilbach, 2006; Yung, 2009; Xue and Klein, 2010; Chavis et al., 2011; Klapper and Love, 2011).

In this section, we explain policy instruments pertinent to comparing the 50 U.S. states. Subsection 2.1 compares the institutional setting in different states in terms of the size of government, taxation, and labor policies. Subsection 2.2 discusses other policy instruments pertinent to the institutional setting, as well as specific government expenditure programs specific to the U.S. context.

\subsection{Institutional Setting}

In this subsection we examine and discuss the role of government transfers and subsidies, takings and discriminatory taxation, labor policies, and bankruptcy law in entrepreneurship, venture capital, and innovation. The next subsection discusses direct government programs.

\subsubsection{Government Transfers and Subsidies}

Arguments in support of government transfers and subsidies stimulating entrepreneurship require that government is well informed. On one hand, if the government policymakers are well informed about the productivity across all current and potential future entrepreneurs, then redistributive policies with transfers and subsidies can be optimally designed to mitigate distortions (Keuschnigg and Nielsen, 2003). Transfers and subsidies not only redistribute between persons of different productivity but also in different states of nature. Government policy can be used to bring effective education and training to an efficient level where private markets do not work well. Government policy can overcome capital gaps in financing entrepreneurs where investors face institutional constraints on financing entrepreneurship. Government transfers may also provide endowments to potentially skilled entrepreneurs to stimulate risk taking, and facilitate agglomeration and information sharing. On the other hand, arguments against transfers and subsidies for the most part are based on the premise that it is highly unlikely that government policymakers are well informed about productivity across all current and potential entrepreneurs in practice. As such, transfers and subsidies are more likely to 
create distortions (Xue and Klein, 2010). The composition of government transfers and subsidies may induce moral hazard and adverse selection costs that mitigate the quality and quantity of entrepreneurial activity, thereby encouraging inefficient business creation and continuation, while at the same time stifling efficient business creation.

In addition to government transfers and subsides, business creation, venture capital and innovation may be influenced by the size of government per GDP, as well as the amount of social security payments per GDP in each state. On one hand, a greater government sector and social security payments may induce risk taking and entrepreneurial activity. On the other hand, it is plausible that the size of government and social security mitigates entrepreneurship as governments are more likely to pursue superfluous activity as they expand (Karabegovic and McMahon, 2008), thereby diminishing the entrepreneurial climate in a region. There are both protective and productive functions of government, and it is plausible that all of the state governments in the U.S. are at a sufficient size to perform the sufficient amount of both of these functions, and if so, this may imply that larger governments are more likely to pursue activities that are unrelated to stimulating business creation. Further, social security payments for retirement, disability insurance and the like that are mandated by the government reduce flexibility and freedom of contract, thereby potentially imposing terms that might otherwise be at an inefficient level and in turn stifling business creation.

\subsubsection{Taxation}

Taxation in the U.S. is progressive in the sense that higher earners pay higher tax rates. Theoretical work has well established the proposition that progressive taxation reduces the returns to entrepreneurship and induces entrepreneurial moral hazard (Keuschnigg and Nielsen, 2004).

Of course, taxes which are at such a low level where the rule of law and other necessary elements are not in place to conduct economic activity, an increase in taxation can stimulate entrepreneurial activity. But as long as taxes are at a level to cover sufficiently productive and protective functions of government (which is likely the case in all of the U.S. states), progressive taxation lowers the marginal benefits to additional effort, reduces the returns to risk taking and generally stifles entrepreneurial activity.

Note that taxation and government transfers and subsidies are not necessarily the opposite sides of the same balance sheet. However, there are many intergovernmental transfers that break 
the link between taxation and spending at the state level. Therefore, it is relevant to assess separately taxation and spending. Further, note that differences between corporate and income taxation can impact the choice between employment and entrepreneurship. Higher corporate taxes relative to higher income taxes are expected to be associated with lower levels of new business starts (Keuschnigg and Neilsen, 2003, 2004). We empirically assess the difference between corporate and income taxes in our empirical analyses.

\subsubsection{Labor Frictions}

Labor laws and the labor environment may impact entrepreneurship, venture capital and innovation through minimum wage legislation, the number of government employees, and labor union density. On one hand, minimum wage legislation might create a social and economic climate that is safe, equal and fair, thereby attracting a higher number and higher quality supply of labor. On the other hand, minimum wage legislation potentially discourages entrepreneurial activities as smaller firms have a diminished ability to afford low-skilled workers at the established minimum wage.

In addition to minimum wages, we assess the impact of government employment. On one hand, higher levels of government employment may create economic opportunities for entrepreneurs to start new firms and conduct business with government, particularly where government expenditures enable agglomeration, for example. On the other hand, higher levels of government employment may give rise to greater labor market competition in a state, thereby diminishing the ability of entrepreneurs to effectively start new businesses. Further, higher levels of government employment could give rise to crowding out of goods and services that might otherwise have been provided privately, thereby stifling business creation.

Unions comprise a third crucial element of labor policy. In principle, workers should have the right to join or form unions. Well functioning voluntary unions have the potential to enhance working conditions and improve the climate for creating new firms. But laws and regulations that mandate labor unions or the joining labor unions where workers would rather not potentially stifle business creation. Factors that affect labor union density in a state include laws and regulations, the size of government, manufacturing density and the size of rural versus urban population. Recent work empirically shows labor unions increase the cost of equity, as they 
decrease a firms operating flexibility (Chen et al., 2011), and as such we would expect fewer start-ups in regions with stronger union density.

\subsubsection{Bankruptcy law}

There are many different elements of bankruptcy laws, and empirical evidence within the U.S. and across countries consistently supports the view that, regardless of more entrepreneur friendly bankruptcy laws support the entrepreneurship (Fan and White, 2003; Armour and Cumming, 2008) and venture capital (Armour and Cumming, 2006). In the U.S., the most variable instrument in bankruptcy laws across states and over time is the homestead exemption (Fan and White, 2003), and as such, it is the variable that we use in our analyses. Some states provide no such exemption (Maryland and Delaware), while others only protect property up to a certain value, and still others are unlimited (Texas, Florida, Minnesota, Oklahoma, Kansas, Arkansas, Iowa, and South Dakota). If the homesteads value exceeds these limits creditors may force the sale.

On one hand, the incentives to undertake risky entrepreneurship are higher with higher homestead exemptions. Note, however, that on the other hand potential agency problems are higher which in turn may discourage investors from financing entrepreneurs in states and periods with higher homestead exemptions. With the recent financial crisis, these agency problems may be viewed as being more pronounced. We therefore test these competing hypotheses over different time periods in the dataset, as presented starting in section 3 below.

\subsection{Direct Public Expenditure Programs}

In this subsection we discuss other policy mechanisms that might influence entrepreneurship, venture capital finance, and innovation. These include the SBIR program (subsection 2.2.1), business incubators (subsection 2.2.2), education and academic R\&D (subsection 2.2.3). Further, in subsection 2.2.4 we comment on the causal relation between entrepreneurship and venture capital finance and innovation.

\subsubsection{SBIR Program}


The Small Business Innovation Research (SBIR) program is coordinated by the Small Business Administration and started in 1982. The SBIR program awards contracts or grants to small businesses typically with fewer than 25 employees. The SBIR program is large. In 1995, there were over \$2.4 billion in SBIR awards (compared with \$8.0 billion among venture capital), while in 2010 there were over \$1billion in awards (compared with \$23.3 billion among venture capital). The awards do not exceed $\$ 750,000$. Awards are based on a multi-governmental selection process in which research potential is assessed, not commercial viability.

Academic work has show that firms that received an SBIR award are much more likely to subsequently receive VC funding in later years, relative to a matched set of firms that did not receive an SBIR award (Lerner, 1999). Moreover, Lerner shows that SBIR awardees also have higher sales and asset growth. Lerner argues that whether or not an award is granted is more important than the size of the award, consistent with the certification rationale for government programs. There does not appear to be an crowding out of private investment with SBIR awards, particularly since the funding is based on research potential, and facilitates signals of quality that private sector investors can use to make more informed investment decisions. Overall, prior evidence on the SBIR program is highly consistent with the view that SBIR awards promote entrepreneurship, venture capital, and innovation.

\subsubsection{Business Incubators}

Business incubators and advisory services are one of the most ubiquitous and persistent forms of government support. Partially or fully publicly funded advisory services are continuously undertaken in nearly every developed country (Hjalmarsson and Johansson 2003). Given how long many of these programs have been in existence, it is not surprising that most have their origins in public policy goals of supporting SMEs. Evidence on the success of these programs, however, is difficult to track due to selection and endogeneity issues, and lack of systematic data on outcomes from such centers (Cumming and Fischer, 2012). On one hand, these programs may stimulate entrepreneurship, attract venture capital, and promote innovation to the extent that coaching and support services fill a needed service. On the other hand, these programs may be more likely to be put into economically depressed areas and attract entrepreneurs that are in greater need of support. In our current study, our question is whether such incubators help to encourage entrepreneurial births, mitigate deaths, and facilitate venture capital investing, and patenting activity. 


\subsubsection{Education and Academic R\&D}

Education and academic research may be related to entrepreneurship, venture capital and innovation (Xue and Klein, 2010). For instance, it is possible that there are educational barriers to starting up a new firm (Levie \& Autio, 2008). That is, where educational levels are deficient, entrepreneurs will not have the necessary skills and access to information that will help them to start new firms. Similarly, university or academic R\&D may give rise to spillover benefits associated with high quality new firm creation, thereby in a pronounced way attracting venture capital and stimulating patents (Breznitz, 2005). We test for both of these effects in our empirical analyses.

\subsubsection{Causal Relation between Entrepreneurship, Innovation, and Venture Capital}

The causal relation between entrepreneurship, innovation, and venture capital is ambiguous. Entrepreneurs seek capital, and capital leads to the formation of entrepreneurs (Adrieu and Groh, 2012; Bascha and Walz, 2001; Jeng and Wells, 2000; Kanniainen and Keuschnigg, 2003; Wang and Wang, 2012a; Yung, 2009). Likewise, patents may cause, or be caused by, new firm formation and new venture capital investment (Audretsch and Feldman, 1996). In our empirical tests we lag all of our right-hand-side variables to address these causality concerns as best as possible. Also, we discuss other robustness checks for causality.

Finally, we note that our theoretical discussion above and empirical tests below do not account for all possible variables. Many other factors that we considered, however, do not significantly vary over time and/or across states. We do include year and state fixed effects to account for these unobservable factors, as discussed below.

\section{Data and Summary Statistics}

\subsection{Data}

Table 1 reports the definition and descriptive statistics of all variables. We first collected from the U.S. Census Bureau a list of state level starts and deaths data for establishments with 14, 5-9 and 10-19 employees for the period from 1995 to 2010(Q1). The data includes annual 
births, birth rate, net change, and net rate of change of establishments for 50 states. The establishment data is measured at the first quarter of each year. For example, the U.S. establishment births of year $t / t+1$ are those businesses which have zero employment in the first quarter of the year $t$ and positive employment in the first quarter of year $t+1$. Our sample includes 800 state-year observations.

\section{[Insert Table 1 About Here]}

The broad public policy variables are captured by the index of economic freedom from the Economic Freedom of North America, published by the Fraser Institute (Karabegovic and McMahon, 2008). Widely used in the literature (e.g., Xue and Klein, 2010), the economic freedom index examines the key aspects of public policy environment. It consists of three primary indices: 1) Size of Government index; 2) Takings and Discriminatory Taxation index; and 3) Labor freedom Index. The Fraser institution calculates the value for all three variables for each state and year. Size of Government index measures the government intervention in the economy, consisting of four components including general consumption expenditures by government as a percentage of GDP, transfers and subsidies as a percentage of GDP and social security payments as a percentage of GDP. Takings and Discriminatory Taxation index has three components: total tax revenue as a percentage of GDP, top marginal income tax rate and the income threshold at which it applies (Karabegovic and McMahon, 2008), indirect tax revenue as a percentage of GDP, and sales taxes collected as a percentage of GDP. Total tax revenue accounts for various corporate and capital taxes not included in the other three components. Capital gains taxes are picked up in total tax revenues, and do not significantly differ across U.S. states (http://www.taxfoundation.org). Labor freedom Index includes minimum wage legislation, government employment as a percentage of total state/provincial employment and union density. Our index for minimum wage is based on the minimum wage per GDP per capita. GDP per capita is a proxy for the average productivity in a jurisdiction. A higher ratio of minimum wage to GDP per capita reflects a narrowing range of employment contracts that can be freely negotiated; for example, minimum wages at $1 \%$ [5\%] of average productivity likely have a small [large] impact on business creation. Reliable data about the quality of unions across states and over time is difficult; therefore, the index of labor unions focuses on overall union density, or the percentage of unionized workers in a state. 
The value of each component is first calculated and then transformed into a value between zero and ten using the formula: $\left(\mathrm{V}_{\max }-\mathrm{V}_{\mathrm{i}}\right) /\left(\mathrm{V}_{\max }-\mathrm{V}_{\min }\right) * 10$, where $\mathrm{V}_{\max }$ is the largest value for the component in that year, $V_{\min }$ is the smallest, and $V_{i}$ is the observation to be transformed. The value of a variable is an equal weighted value of its components). The indices are a relative ranking. (For details, see Karabegovic and McMahon, 2008). The three public policy variables exhibit both cross-sectional and time series heteroskedasticity. A high score indicates a smaller role for government intervention. We also look into other public policy measure such as the Index of Economic Freedom (HF index) is published by Heritage Foundation. ${ }^{1}$ The HF index is constructed at country level, making it unsuitable for our state-level analysis. Comparing the two measures at country level demonstrates that the Fraser index able to well capture various aspects of the regulatory framework and institutional environment, which might affect business creation and operation. The two indices overlap in their coverage and original data sources to a large extent - both measure government spending, tax burden, labor market regulations. The two government consumption sun-indices are highly correlated, with a correlation coefficient of 0.87 , significantly at $1 \%$ level. We also observe high correlation between the indices measuring the difficulty of starting and operating a business. The correlation coefficient of tax burden is 0.39 , significant at the $1 \%$ level.

It is worth mentioning that there is a one-quarter lag between the business creation variables and public policy indices, since the former is computed at the end of the first quarter of each subsequent year but the latter is calculated for the calendar year. As a result, there might be a lead-lag relationship between the public policy indices and business establishment data considering the time needed for the economic policies to take effective. Below, we empirically assess this possibility to allow for an additional 1 year lag (over and above the 1 quarter lag) and find the results to be robust.

We manually collected data on direct public expenditure programs. The number of Small Business Innovation Research Awards is obtained from the SBIR/STTR website. ${ }^{2}$ The number of business incubators is available on the National Business Incubation Association (NBIA)

\footnotetext{
${ }^{1}$ We thank the anonymous referee for suggesting the use of this database.

2 http://www.sbir.gov/
} 
website. ${ }^{3}$ Data on academic science and engineering R\&D are drawn from the State Science \& Technology Institute website. ${ }^{4}$

The MoneyTree Report published by PricewaterhouseCoopers and the National Venture Capital Association report the number of venture capital deals by state on a quarterly basis, which are aggregated to the state level. Panel data on the number of utility patents granted are drawn from the United States Patent Trademark Office website.

Following the literature, we control for a set of variables that are likely to affect business creation. The homestead and personal property exemption data are from Berkowitz and White (2004), Fan and White (2003), and Pettit and Platte (2011). The Tax Foundation website lists the top marginal corporate and top marginal Income Taxes. Data on Education, personal income and real GDP are obtained from the U.S. Bureau of Economic Analysis.

\subsection{Summary Statistics}

Table 1 indicates that the average state level establishment births decreases substantially in the size of the business, varying from 1,648.48 per 1 million people for business with 1-4 employees to 147.11 for that of establishment with 10-19 employees. The establishment birth rates reveal the same pattern, decreasing from $16.39 \%$ for $1-4$ employees to $6.12 \%$ for $10-19$ employees. The average establishment change per 1 million people, which considers both births and deaths, is 83.91 for size 1-4 business, while the total establishments for size 10-19 business seldom changes, with a an average of 4.13 . The establishment change rate, exhibiting the same pattern, varies from $0.79 \%$ for $1-4$ business to $0.17 \%$ for establishment with $10-19$ employees.

Table 1 further indicates that the Size of Government index varies from a low value of 2.49 (Mississippi in 2006) to a high of 9.1 (Delaware from 1997 to 2000), with an average of 7.02. The Takings and Discriminatory Taxation index is relatively lower. Its average is equal to 5.92, varying from 3.54 (South Carolina in 2006) to 8.60 (Delaware in 2004). Similarly, the mean Labor Index is 7.12, with a minimum of 5.5 (Hawaii in 1997 and 1998) to a maximum of 8.41 (Texas in 2007).

${ }_{4}^{3} \frac{\text { http://www.nbia.org/ }}{\text { http://www.ssti.org }}$ 
The average difference between top marginal corporate income tax and individual top marginal tax is $-1.58 \%$. The number of utility patents per 1000 people varies from 0.03 to 1.36 , with an average of 0.24 . The average state-level homestead exemption is $\$ 66,628$, with a minimum of 0 and a maximum of $\$ 550,000$. On average, $22.15 \%$ of persons 25 years old and over has a bachelor's degree or more. The state-level person income grows at $-0.14 \%$ on average.

States differ in their efforts to set up business incubators to support development of entrepreneurial companies, ranging from 0 to 4.72 (North Dakota in 2006), with an average of 0.91. Rhode Island has no business incubators throughout our sample period. Most states have at least one business incubator from the beginning of our sample period. On average, 15.34 Small Business Innovation Research awards are granted at state level in each year for every 1 million people. Massachusetts won 146.92 awards in 2002, the highest in our sample. Academic science and engineering $R \& D$ varies from 0 to $\$ 15.60$ million, resulting in an average of 12.04 . The average number of venture capital deal per 1 million people is 8.21 ; while the total dollar value of venture capital investment per 1000 people is $\$ 51,683$.

Table 2 provides comparison of means and medians tests of U.S starts and deaths data for establishments in relations to different levels of the three major policy indices from the Fraser Institute. For each index, the whole sample is classified into High or Low group based on whether the index value is higher or lower than its median. Higher values of each of the three indices imply less government intervention. We compute the mean and median value for both groups and test whether there is statistically difference between them. We show the results for new establishment births (Panel A), birth rates (Panel B), net changes in births - deaths (Panel C), net rate of change of births - deaths (Panel D), and for venture capital deals and dollars and patents (Panel E).

[Insert Table 2 About Here]

Table 2 Panel A reports the comparison results of Establishment Births per million population for the full sample of all state-years. The mean and median differences are positive significant at $1 \%$ for the high and low Size of Government index for all business sizes in Panel A, rates of change in Panel B, net changes in births - deaths in Panel C (with the exception of means and medians the 10-19 category), net rates of change in Panel D (with the exception of median 
values), and venture capital deals and dollars, and patents in Panel E, which suggests smaller governments facilitate entrepreneurship, venture capital and innovation.

Higher levels of the takings and discriminatory taxation index is associated with fewer business starts for firms with 1-5 and 5-9 employees, but an insignificant difference for firms with 10-19 employees (Table 2, Panel A), but a higher rate of change in firms with 1-4 and 10-19 employees and a lower rate of change in firms with 5-9 employees (Panel B). The net change (Panel C) and net rate of change (Panel D) show higher takings and discriminatory taxation show significantly higher figures for new establishment births-deaths for 10-19 employees (Panel C), and higher median rates of change values for 5-9 employees, and higher means and medians for rates of change for 10-19 employees (Panel D). Panel E shows the takings and discriminatory taxation index is significantly negatively associated with mean levels of venture capital deals and venture capital dollars, but insignificantly related to the median values and insignificantly related to patents.

Finally, Table 2 shows that a higher Labor Freedom Index is associated with higher levels of firm establishments (Panel A), higher levels of rates of change in firm establishments (Panel B), higher net changes in births - deaths (Panel C), higher levels of rates of change in births - deaths (Panel D). Those differences are all significant for both means and medians in Panels A-D. Further, Panel E shows higher levels of the Labor Freedom Index is associated with higher levels of venture capital deals and dollars in Panel E for both means and medians. However, the Labor Freedom Index is unrelated to patents. Less strict labor market regulations spur venture capital investment, consistent with theoretical models predicting that stricter labor policies discourage innovative activities (Saint-Paul 1997, 2002; Samaniego, 2006), and empirical evidence from Europe (Bozkaya and Kerr, 2013). Note that this result is consistent with that that reported in Sobel (2008), which considers cross-state differences for a single year without considering any time series variation in the data at all. In this paper we consider both cross-state differences as well as the time dimension in the data since new business starts, venture capital and patents are highly volatile from one year to the next, and as such, to accurately assess policy one needs to consider a large number of years and not judge policy on the basis of a single year. Actually, Sobel (2008) does not report difference tests and aggregates different measures of the size of government together and only reports regression coefficients, do it is difficult to ascertain whether the results for the single year considered would actually materialize in the summary statistics. Regardless, in this paper we consider a full set of available years in the data. 
Below, we assess in with the use of panel data regressions whether these results hold in a multivariate setting.

Table 3 presents comparison tests for other policy instruments other than the Fraser Indices, including the homestead exemption, the number of business incubators, academic science and engineering $R \& D$, and the number of SBIR awards (we do not present comparison tests for education for reasons of conciseness and because those tests were less often statistically significant). The data indicate that the homestead exemption is positively and significantly associated with higher mean and median levels of establishment births (Panel A), and rates of change in establishment births (Panel B). The homestead exemption is statistically unrelated to levels of births - deaths (Panel C) and unrelated to rates of change in births - deaths (Panel D). The homestead exemption is positively and significantly associated with the mean level of venture capital deals and dollars, as well as the mean and median level of patents, but negatively associated with the median level of venture capital deals and dollars (Panel E).

\section{[Insert Table 3 About Here]}

Table 3 further shows that the number of business incubators is negatively associated with the number of establishment births (Panel A), rate of change in births (Panel B), births deaths (Panel C), rate of change in births - deaths (Panel D), and venture capital deals, dollars and patents (Panel E). Each of these effects for business incubators is statistically significant with the exception of mean and median differences in births - deaths for 10-19 employees, mean and median differences in rates of change for 10-19 employees, and the mean levels of patents (Panel E). Academic R\&D is significantly negatively associated with new establishment births (Panel A), unrelated to rates of change in establishment births (Panel B, with the sole exception of positively associated with median levels for firm size 1-4), unrelated to births-deaths and rates of change in births - deaths (Panels C and D), but positively associated with venture capital deals and dollars, as well as patents (Panel E). Finally, SBIR awards are significantly positively associated with new establishment births (Panel A), rates of change in new establishment births (Panel B, with the sole exception of firm sizes 10-19), births - deaths and rates of change in births - deaths (Panels C and D), and venture capital deals and dollars, as well as patents (Panel E).

Table 4 presents a correlation matrix for the main variables used in the multivariate tests provided in the next section. The correlations are consistent with the comparison tests in Tables 2 
and 3 discussed above. The next section explores these relationships further in a multivariate context and with consideration to collinearity and causality issues, among other things.

\section{[Insert Table 4 About Here]}

\section{Regression Analyses}

Our regression analyses for the quantity of new business creation in terms of new business starts and business starts - deaths are presented in Tables 5 and 6, respectively. Thereafter, in Table 7 we present regressions for quality, as proxied by the number and dollar value of venture capital deals and patents. By considering regressions with state and year fixed effects, and controlling for other things being equal, the impact of the policy instruments in some cases is distinct from that which is apparent from the summary statistics reported above in section 3. For conciseness, we present regressions in levels and not rates of change. Results for regressions in rates of change produced similar inferences and are available on request as well as available in earlier versions of this paper. Below, we explicitly show regressions for the full sample, as well as separately for the financial crisis years 2008-2010. In this section we first discuss the main regression results in subsection 4.1. Subsection 4.2 discusses additional robustness checks.

\subsection{Main Regression Results}

In Table 5 we panel regressions with year and state fixed-effects to account for differences across years and states that are not picked up by our time-varying policy variables of interest. Our regression models are of the following form:

(1) New Business Creation / Population = f (Lag GDP / Population, Lag Size of Gov. Index Combining 1A/1B/1C, Lag Takings and Dis. Tax Index Combining 2A/2B/2C, Lag Labor Freedom Index Combining 3A/3B/3C, Corporate - Income Taxes, Lag Number of Venture Capital Deals / Population (*100), Lag Patents / Population, Homestead Exemption, Lag Education, Lag Number of Business Incubators / Population, Lag Number of Small Business Innovation Research Awards / Population, Lag Personal Income Growth, Lag Academic R\&D per GDP). 
In Table 5, Models 1 and 4 consider factors that affect the level of business starts with 14 employees relative to the population in the state; Model 1 shows the full sample from 19952010, while Model 4 shows the subsample in the financial crisis years 2008-2010. Models 2 and 5 are analogous to Models 1 and 4, respectively, with the difference being that they consider starts with 5-9 employees. Models 3 and 6 are analogous to Models 1 and 4, respectively, with the difference being that they consider starts with 10-19 employees. We note that all of our variables are scaled by population in the state/year, with the exception of academic R\&D which is scaled by the state-year GDP; the reason for this scaling is that academic R\&D / population is too highly correlated with GDP/population to include in the same regression model. Also, the homestead exemption is expressed in levels, and corporate - income taxes and personal is expressed in rates. In Table 6 we present regression Models 7-12, which are completely analogous to Models 1-6, with the sole exception that in Models 7-12 the dependent variables are measured as Births Deaths. All of the models exhibit high adjusted $\mathrm{R}^{2}$ values. In Table 7 we present regression Models 13-18, which are again analogous to Models 1-6, with the exception that the dependent variables are venture capital deals, venture capital dollars, and patents (each scaled by population), and the right hand variables include similar variables as in equation (1) but also include lagged values of new establishments, and lagged values of venture capital deals (for the patent regressions) and lagged values of patents (for the venture capital regressions).

\section{[Insert Tables 5, 6 and 7 About Here]}

The data are consistent with the view that higher levels of Takings and Discriminatory Taxation is harmful to the quantity new establishments with 1-4 employees in normal economic times, but otherwise generally beneficial in terms of helping new establishments, mitigating establishment deaths, and helping venture capital, particularly in time of financial crises. In particular, the data indicate in regression Model 1 in Table 5 that there is a positive association between the Takings and Discriminatory Taxation Index and new establishment births, and this effect is significant at the $1 \%$ level. The economic significance is such that a 1 -standard deviation increase in the Takings and Discriminatory Taxation Index is associated with a 1.7\% increase in establishment births relative to the mean value. The Takings and Discriminatory Taxation Index is insignificant in Models 2-5, however, and negative and insignificant in Model 6 for firms with 10-19 employees and the financial crisis years 2008-2010. Moreover, the Takings and Discriminatory Taxation Index is negative and significant in Models 8, 11 and 12 for births deaths, where the economic significance is such that a 1-standard deviation increase in the index 
is associated with a 1.9\% (Model 8), 5.5\% (Model 11) and 5.9\% (Model 12) reduction in birthsdeaths for 5-9 employees in the full sample (Model 8), 5-9 employees in the 2008-2010 subsample (Model 11) and 10-19 employees in the 2008-2010 subsample (Model 12), respectively, Further, in Models 13 venture capital deals in the full sample and venture capital dollars in the 2008-2010 subsample, respectively, a 1-standard deviation increase in the Takings and Discriminatory Taxation Index is significantly associated with a $12.9 \%$ decrease in venture capital deals in the full sample.

The importance of taxes is similarly reflected in the differences between corporate and income taxes, which impacts occupation choice. Higher corporate taxes relative to income taxes skews preferences towards employment as opposed to entrepreneurship (Keuschnigg, 2004). In an earlier version of this paper with data up to 2004, we found evidence consistent with this view. However, the data in Table 5 indicate the opposite, which is largely driven by the 2008-2010 years. The economic significance is small: a 1-standard deviation increase in corporate - income taxes is associated with a $0.2 \%$ increase in establishment births with 10-19 employees (Model 3). Model 13 similarly shows a 1-standard deviation increase in corporate - income taxes gives rise to an increase in venture capital deals by $11.6 \%$.

Taken together, the Takings and Discriminatory Taxation Index and the corporate income tax variables for the overall tax burden and the relative levels of taxation do not show much evidence of economic harm in terms of less entrepreneurial activity.

Unlike the Takings and Discriminatory Taxation Index, the data ubiquitously indicate higher levels of Labor Freedom are helpful for new establishment births, mitigate establishment deaths, and help venture capital deals and dollars, even in times of crises; however, there is some evidence that lower levels of Labor Freedom are associated with higher levels of patents. In particular, the data indicate in regression Model 1 in Table 5 that there is a positive association between the Labor Freedom Index and new establishment births, and this effect is significant at the $1 \%$ level. The economic significance is such that a 1-standard deviation increase in the Labor Freedom Index is associated with a $6.8 \%$ increase in establishment births relative to the mean value. This effect is positive and significant in Models 3, 4, and 5, where the economic significance is $2.1 \%, 5.3 \%$, and $6.6 \%$, respectively, thereby indicating the effect is more pronounced in times of crises. Similar patterns are also observed in Models 7, 8 and 9. The establishment births - deaths increase by $3.5 \%-7.1 \%$ for 1 -standard deviation increase in the 
index. Further, this effect is positive and significant in Models 13, 14 and 16, with the economic significance of a 1-standard deviation change at $27.0 \%, 54.6 \%$ and $25.3 \%$, respectively, for venture capital deals and dollars in the full sample and in the financial crisis. Overall, therefore, Labor Freedom appears to be very important to entrepreneurship and venture capital. Also, in Models 15 and 18 for patents in Table 7, we note that the effect of Labor Freedom is negative and significant at the $1 \%$ level, with the economic significance of a 1-standard deviation change at $13.1 \%$ and $-15.7 \%$, respectively. We interpret this latter result as suggestive that legal conditions which afford greater security enable more explorative actions among firm employees, thereby generating more innovation (consistent with Manso, 2011).

There is mixed evidence on the value of the size of government. The data highlight a negative effect of the Size of Government Index in Model 2 for firms with 5-9 employees (the economic significance of a 1-standard change is $-2.9 \%)$. But this effect is reversed for the subset of the years 2008-2010 in Model 5 for firms with 5-9 employees (the economic significance is 6.6\%). In other words, larger governments crowd-out start-up activity in normal times, but facilitate start-up activity in times of financial crises. Models 7 and 8 demonstrate that the Size of Government Index is negative and statistically significant for net change in business establishment for size 1-4 and 5-9 businesses. For every 1-standard deviation increase in the index, the establishment births - deaths drop for 4.6\% (size 1-4 firms) and 3.6\% (size 5-9 firms), respectively. This effect is not robust in models in Table 7.

The effect of bankruptcy laws is measured by the real constant dollar level of the homestead exemption, and the data generally highlight a negative effect of the homestead exemption on new establishment births, net change in establishment and venture capital, and a mitigating effect on business deaths. In particular, the impact of higher homestead exemptions is negative for new establishment births in Table 5 Models 1, 2, and 5, where the economic significance of a 1 -standard deviation change is $-1.8 \%,-1.2 \%$, and $-30.7 \%$, respectively.

Given our findings with respect to the homestead exemption differ from that reported by other studies such as Fan and White (2003), we considered the stability of this estimate to a large number of robustness checks, including for example different subsets of years, different treatment of the unlimited exemption states such as excluding the unlimited exemption states and the use of proxies for different magnitudes to reflect the economic benefit for home expenditures, exclusion of different explanatory variables (such as only running the regression with the state and year 
fixed effects and the homestead exemption), and different subsets of the data for different levels of the homestead exemption. The only case in which we were able to generate a significant and positive coefficient for the homestead exemption was for the bottom quartile homestead exemption states (giving rise to a sample of 156 state-year observations), for which a parsimonious regression with only the homestead exemption variable gave rise to a positive and significant coefficient at the $1 \%$ level whereby the economic significance was such that a 1standard deviation increase in the homestead exemption was associated with a $6.1 \%$ increase (relative to the mean) in the number of business starts with 1-4 employees. With a complete set of variables as reported in Model 1, however, this effect was insignificant.

The data show mixed evidence from the impact of business incubators. In Table 5 business incubators have a positive and significant effect in Model 2 (the economic significance of a 1-standard deviation change is $1.3 \%$ ) and 6 (economic significance $10.4 \%$ ), but a negative and significant effect in Models 4 (economic significance -4.9\%). In Model 7, 9 and 12 in Table 6 there is a positive and significant effect of incubators (economic significance 3.0\%, 2.3\% and 13.6\% in Model 7, 9 and 12, respectively), but this effect is insignificant in each of Model 13-18. Arguably, our business incubator variable is endogenous, and relatively more endogenous to our other policy variables. We discuss this issue further below in subsection 4.2.

The data highlight a positive effect of academic R\&D on new establishment births, but a new impact on births - deaths, and a negative impact on venture capital deals and dollars. In particular, in Models 1, 2, and 5, for new establishment births, academic R\&D is positive and statistically significant with the economic significance such that a 1-standard deviation change giving rise to a $3.1 \%, 6.05 \%$, and $37.0 \%$ increase in new establishments, respectively. However, the impact in Table 6 Model 12 is negative, with a 1-standard deviation change reducing births deaths for establishments with 10-19 employees by $48.7 \%$. Moreover, in Table 7 the effect is also negative in Models 13, 14, 16, and 17, significant at 5\% level.

Higher levels of education, as proxied by the fraction of individuals with a bachelors degree, tend to show lower levels of entrepreneurship, except in times of financial crisis. The only positive effect of education is seen in Models 4 and 5 for the financial crisis period, where the data indicate a 1-standard deviation increase in education is associated with a $4.6 \%$ and $3.5 \%$ increase in new business starts, respectively. By contrast, the data indicate a negative and significant effect in Model 3 for new establishment births, but this effect is not economically 
significant. There is a negative and significant effect for births - deaths in Models 7-9 (again not economically significant) and Model 12 (a 1-standard deviation increase gives rise to a reduction by $15.4 \%$ ), and a negative and significant effect in Model 15 (economic significance -17.8\%).

SBIR awards unambiguously show a positive effect on entrepreneurship and venture capital. In particular, a 1-standard deviation increase is associated with a $46.5 \%$ increase in new establishment births for 10-19 employees (Model 3), a 28.4\% increase in new establishment births in the financial crisis for 10-19 employees (Model 6), while a 0.18\% decrease in births deaths for 10-19 employees (Model 9), and a 13.7\% increase in venture capital deals (Model 13), $33.9 \%$ increase in venture capital dollars (Model 14), and a 21.4\% increase in venture capital deals during the financial crisis of 2008-2010 (Model 16).

The control variables for economic factors, including PI growth and GDP / capita, are significant in ways that we would expect. PI growth is positive and significant in Model 5 and 6, while GDP per capita is positive and significant in Model 5, indicating more entrepreneurial activity in more prosperous regions during the financial crisis. Similarly, PI growth is positive and significant in Model 11, and GDP / capital is positive and significant in Models 10, 11, as well as Models 15 and 18. There is evidence that PI growth is negative and significant in Models 9 and 10, and GDP / capital is negative and significant in Models 7 and 9. One interpretation of these results is that low income may drive more people to start new businesses to create opportunities for themselves (consistent with Thurik et al., 2008). Further examination of differing roles of economic conditions and possible nonlinearities is warranted but beyond the scope of this paper. Further, we stress that the results are robustness to state fixed effects to pick up factors not controlled for the in regressions but which might systematically differ across states.

Finally, we note that the economic conditions in terms of patents and venture capital are significant. Patents have a positive and significant effect in Model 1 for business starts with 1-4 employees and for establishment births - deaths in Model 7 and 8. We would not expect all new firms to be able to patent at an early stage or there may be delays in innovations after new firms start, and not all innovations take place in new firms (e.g., Cassiman and Ueda, 2006). There is a positive and significant effect in Models 13 and 14 for venture capital deals and dollars, consistent with related work showing dual causality between venture capital and patents (Ueda and Hirukawa, 2008). Venture capital deals are insignificant in insignificant in Models 1-6, 8-12, 
and Model 15, but positive and significant in Model 18, consistent with the view that venture capital facilitates innovative activity (Lerner, 1999, 2009).

\subsection{Additional Robustness Checks, Limitations, and Extensions}

Our regression analyses considered a variety of robustness checks, many of which were explicitly reported, others that were reported in an earlier draft, and others considered but not reported. For instance, in an earlier draft of this paper we reported regressions for changes in levels, and the findings are quite consistent. Likewise, we considered different possible variables to include or exclude, and again, the findings reported above do not materially change. Of course, there are other policy instruments to stimulate entrepreneurship, such as public loan guarantees ( $\mathrm{Li}, 2002)$, as well as other economic factors such as agglomeration that could explain state level different in business creation. In our specifications we used state fixed effects to pick up state differences not captured in the policy variables considered. Further work could explore differences in other factors and over time to understand the relative importance of variables not explicitly measured herein.

In our empirical analyses we study the period from 1995 to 2010. We considered subperiods, and showed some differences in the findings in reference to the recent financial crisis of 2008-2010. In the analysis of the influence of government transfers on business starts, startsdeaths, venture capital and patents, we examine both direct governmental programs such as the SBIR awards program, as well as the institutional setting in different states.

Our analyses consider new establishments as our main dependent variables in Tables 5 and 6, as recorded by the U.S. Census (Table 1). We believe these data appropriately measure entrepreneurial activity in terms of new business starts, as well as entrepreneurial activity among smaller firms setting up new offices in different geographic regions. We considered other data sources to proxy for entrepreneurship across the U.S. states and found a high degree of correspondence across different datasets. Certainly an advantage of the U.S. Census data is the completeness, and the ability to track not only new establishment births but also births - deaths.

One possible concern is in terms of endogeneity. We lagged our explanatory variables by 1 year in all of our regressions to mitigate the impact of endogeneity. Because there are a huge number of factors that could affect the broad governmental indices used in this paper apart from 
new establishment births and deaths, we do not believe our indices suffer from significant endogeneity problems. We have explored the possibility of endogeneity with some of the arguably more directly affected variables that could be endogenous such as venture capital and business incubators using instruments as in Samila and Sorensen (2009), but our analyses did not uncover any major differences in our findings. Moreover, exclusion or inclusion of such variables from our regression equations does not materially impact our findings with respect to the other variables.

In this paper we do not make claims about welfare effects (see, e.g., Schumpeter, 1934; Baumol, 1990; North, 1990; Irvine and Wang, 2003). In related theoretical work, Keuschnigg and Nielsen (2003, 2004) find that non-redistributive taxes have neutral welfare implications, while progressive taxes always impair entrepreneurship and the effect on welfare is positive or zero, depending on the specification of incentives in the model. Similarly, Sobel (2008) and others discuss the role of policy in influencing proxies for the quality of entrepreneurship, but this analysis is not based on time series changes in public policies and rather cross sectional analyses across states. As well, prior work has not fully measured the effects of entrepreneur related policy changes on overall societal welfare. Further, in this paper we do not distinguish between different types of entrepreneurship, such as by race or gender. Our analyses are based on U.S. Census data on overall business starts and deaths. Recent work with survey data from the Kauffmann foundation examines entrepreneurship by race and gender (Fairlie, 2009; Fairlie and Robb, 2009; Fairlie et al., 2009; Cole and Mehran, 2009).

It is noteworthy that the evidence in this paper is in sharp contrast to the findings in Sobel (2008), particularly in relation to the effect of government on venture capital and start-up activity. The reason for these differences is as follows. First, Sobel (2008) assumes a larger government is one of lower quality. The Karabegovic and McMahon (2008) indices used in this paper and in Sobel (2008) measure the size of government, not the quality. Size does not imply quality. Second, we examine the empirics with time-series and cross-sectional data, while Sobel (2008) examines only cross-section data without considering differences over time. Time series changes reveal important relationships between the variables, and it is widely regarded that panel datasets should not be estimated as cross-sectional datasets. There are a few other papers on related topics that are worth mentioning in this context. Gohmann et al. (2008) consider time series and state variation but with different dependent pertaining to service industries, as well as different independent variables. Campbell and Rogers (2007) examine an issue that is closer related to 
Sobel (2008) and this paper, but do not consider time series changes in index values, and restrict their analysis to business starts without examining business starts by different numbers of employees, and do not analyze patents or venture capital activity. Therefore, our approach herein differs first in terms of the theoretical position that larger governments are not necessarily of lower quality, and second in terms of the empirical execution by making use of time series and cross sectional variation in the panel data. The paper closest to our is Xue and Klein (2010), who study policy measures averaged over 1995-1999 and outcome measures average over 2000-2004, and find the importance of a smaller public sector for stimulating entrepreneurial activity, as measured by an aggregation of patents, SBIR awards, venture capital, and technology establishments. Our findings are consistent with Xue and Klein (2010), but in this paper, we take a somewhat different approach by examining a panel data setting, different outcome variables that are not aggregated such as new establishment births, births - deaths, venture capital, and patents, and examine data that includes but is not limited to the recent financial crisis.

In this paper we limit ourselves to the narrow question of how public policy affects business creation in terms of births and deaths, and the change in births and deaths over time, and proxies for entrepreneurial quality in terms of venture capital and patents. Ideally, we would like to be able to track what happened with these new firms that started up in response to policy changes, and how measures of overall state welfare changed in response to policy changes. These questions are beyond the scope of our current data, but would be an interesting avenue for future research.

\section{Conclusions}

This paper empirically examines the relation between business starts and deaths in relation to U.S. public policy using the U.S. state level census data which covers the 1995-2010 period. We did not find evidence that the overall tax burden gives rise to much evidence of economic harm in terms of less entrepreneurial activity. By contrast, labor frictions are significantly associated with lowers levels of entrepreneurial activity and venture capital, albeit labor frictions are associated with higher levels of patents. SBIR awards are consistently associated with higher levels of entrepreneurial activity and venture capital. We analyzed a variety of other policy instruments and compared the effects of policy in regular times with the financial crisis of 2008-2010. These findings are robust to various controls with different 
econometric specifications including state fixed effects, controls for economic conditions, and other factors.

In this paper we do not consider overall welfare impacts of these policies. Rather, we only empirically study business starts and deaths, and proxies for the quality of entrepreneurial activity. Future work could use the new policy indices presented here in conjunction with other data to enable analyses of policy changes on more broadly based welfare implications associated with business creation.

\section{References}

Acemoglu, D., and S. Johnson, 2005. Unbundling institutions, Journal of Political Economy 115, 949-95.

Andrieu, G., and A.P. Groh, 2012. Entrepreneurs' financing choice between independent and bank-affiliated venture capital firms, Journal of Corporate Finance 18, 1143-1167.

Armour, J., and D.J. Cumming, 2006. The legislative road to Silicon Valley, Oxford Economic Papers 58, 596-635.

Armour, J., and D.J.. Cumming, 2008. Bankruptcy law and entrepreneurship, American Law and Economics Review 10, 303-350.

Audretsch, D., 2007. Entrepreneurship capital and economic growth, Oxford Review of Economic Policy, 23, 63-78.

Audretsch D.B., and M.P. Feldman, 1996. R\&D spillovers and the geography of innovation and production, American Economic Review, 86, 630-640

Audretsch, D., and M. Keilbach, 2007. The localisation of entrepreneurship capital: Evidence from Germany. Regional Science, 86, 351-365.

Baumol, W.J., 1990. Entrepreneurship: productive, unproductive and destructive, Journal of Political Economy 98, 893-921.

Bascha, A., and U. Walz, 2001. Convertible securities and optimal exit decisions in venture capital finance, Journal of Corporate Finance 7, 285-306.

Beck, T.H.L., A. Demirgüc-Kunt, L. Laeven, and R. Levine, 2008. Finance, firm size and growth, Journal of Money, Credit and Banking 40, 1379-1405

Berkowitz, J., and M. White, 2004. Bankruptcy and small firms' access to credit, RAND Journal of Economics 35, 69-84. 
Bertoni, F., M.G. Colombo, and L. Grilli, 2011. Venture capital financing and the growth of hightech start-ups: Disentangling treatment from selection effects. Research Policy 40, 10281043.

Bjornskov, C., and N. Foss, 2008. Economic freedom and entrepreneurial activity: Some crosscountry evidence, Public Choice 134, 307-328.

Bozkaya, A. and W.R. Kerr, 2013. Labor regulations and European venture capital, Journal of Economics and Management Strategy, forthcoming.

Breznitz, D., 2005. Diffusion of academic R\&D capabilities as an industrial innovation policy? The development of Israel's IT industry. Available at SSRN: http://ssrn.com/abstract $=753510$

Campbell, N.D., and T.M. Rogers, 2007. Economic freedom and net new firm creation. Cato Journal 27, 23-36.

Cassiman, B., and M. Ueda, 2006. Optimal project rejection and new firm start-ups, Management Science 52, 262-275

Chantrill, C., 2009. U.S. Government Spending as a Percent of GDP. Available at: http://www.usgovernmentspending.com/us_20th_century_chart.html

Chavis, L.W., L.F. Klapper, and I. Love, 2009. The impact of the business environment on young firm financing. World Bank Economic Review 25, 486-507.

Chen, H., M.T. Kacperczyk, and H. Oritz-Molina, 2011. Labor unions, operating flexibility and the cost of equity, Journal of Financial and Quantitative Analysis 46, 25-58.

Cole, R.A., and H. Mehran. 2009. Gender and small firms. Paper presented at the Kauffman Foundation-Federal Reserve Conference on Entrepreneurial Finance held in Cleveland.

Colombo, M.G., and L. Grilli, 2008. Does it take two to tango? Founders' human capital, venture capital and the growth of high-tech start-ups, Available at SSRN: http://ssrn.com/abstract $=1150294$

Cosh, A., D.J. Cumming, and A. Hughes, 2009. Outside entrepreneurial capital, Economic Journal 119, 1494-1533.

Cumming, D.J., and E. Fischer, 2012. Publicly funded business advisory services and entrepreneurial outcomes, Research Policy 41, 467-481.

Denis, D.J., 2004. Entrepreneurial finance : an overview of the issues and evidence, Journal of Corporate Finance 10, 301-326.

Djankov, S., R. La Porta, F. Lopez-De-Silanes, and A. Shleifer, 2002. The regulation of entry, Quarterly Journal of Economics 117, 1-37.

Engel, D., and M. Keilbach, 2006. Firm-level implications of early stage venture capital investment - an empirical investigation, Journal of Empirical Finance 14, 150-167. 
Evans, D.S., and B. Jovanovic, 1989. An estimated model of entrepreneurial choice under liquidity constraints, Journal of Political Economy 97(4), 808-827.

Fan, W., and M. White, 2003. Personal bankruptcy and the level of entrepreneurial activity, Journal of Law \& Economics 46, 543-568.

Fairlie, R.W., 2009. Measuring Entrepreneurship in the United States - the Kauffman Index of Entrepreneurial Activity, Kansas: The Kauffmann Foundation.

Fairlie, R.W., and A. Robb, 2009. Race and entrepreneurial success. Working Paper, University of California, Santa Cruz.

Fairlie, R.W., A. Robb, and D.R. Robinson, 2009. Financial capital injections among new black and white business ventures: Evidence from the Kauffman Firm Survey. Working Paper, University of California, Santa Cruz.

Foss, K., N.J., Foss, and P. Klein, 2007. Original and derived judgment: An entrepreneurial theory of economic organization, Organization Studies 28, 1893-1912.

Foss, K., N.J., Foss, P. Klein, and S. Klein, 2007. The entrepreneurial organization of heterogeneous capital, Journal of Management Studies 44, 1165-1186.

Foss, N.J., P. Klein, and P.L. Bylund, 2012. Entrepreneurship and the economics of the firm, in D. Hjorth, ed., Handbook on Organizational Entrepreneurship, Cheltenham, U.K.: Edward Elgar, Chapter 3, pp.49-63.

Fossen, F.M., 2011. The private equity premium puzzle revisited - new evidence on the role of heterogeneous risk attitudes, Economica 78, 656-675.

Gaston, N., and D. Nelson, 2000. Immigration and labour-market outcomes in the United States: A political-economy puzzle, Oxford Review of Economic Policy 16, 104-114.

Glaeser, E.L., R. La Porta, F. Lopez-de-Silanes, and A. Schleifer, 2004. Do institutions cause growth? Journal of Economic Growth 9, 271-303.

Gohmann, Stephan F.; Hobbs, Bradley K.; McCrickard, Myra, 2008. Economic Freedom and service industry growth in the United States. Entrepreneurship: Theory \& Practice 32(5), 855-874.

Hjalmarsson, D., Johansson, A. 2003. Public advisory services: theory and practice. Entrepreneurship and Regional Development 15, 83-98.

Imai, Y., and M. Kawagoe, 2000. Business start-ups in Japan: Problems and policies, Oxford Review of Economic Policy 16, 114-123.

Irvine, I., and S. Wang, 2003. The distribution of wealth with uncertain income, Economica 70, 267-292.

Klein, P., J.T. Mahoney, A.M. McGahan, and C. N. Pitelis, 2010. Toward a theory of public entrepreneurship, European Management Review 7, 1-15. 
Jeng, L.A., and P.C. Wells, 2000. The determinants of venture capital funding: evidence across countries, Journal of Corporate Finance 6, 241-289.

Karabegovic, A., and F. McMahon, 2008. Economic Freedom in North America. Vancouver: The Fraser Institute.

Kanniainen, V., and C. Keuschnigg, 2003. The optimal portfolio of start-up firms in venture capital finance, Journal of Corporate Finance 9, 521-534.

Keuschnigg, C., 2004. Venture capital backed growth. Journal of Economic Growth 9, 239-261.

Keuschnigg, C., and S.B. Nielsen, 2003. Tax policy, venture capital, and entrepreneurship, Journal of Public Economics 87, 175-203.

Keuschnigg, C., and S.B. Nielsen, 2004. Progressive taxation, moral hazard, and entrepreneurship, Journal of Public Economic Theory 6, 471-490.

Klapper, L., L. Laeven, and R. Rajan, 2006. Barriers to entrepreneurship. Journal of Financial Economics 82, 591-629.

Klapper, L., and I. Love, 2011. Entrepreneurship and development: The role of information asymmetries, World Bank Economic Review 25, 448-453.

La Porta, R., F. Lopez-de-Silanes, A. Schleifer, and R. Vishny, 1999. The quality of government, Journal of Law, Economics and Organization 15, 222-279.

Lerner, J., 2009. Boulevard of Broken Dreams: Why Public Efforts to Boost Entrepreneurship and Venture Capital Have Failed - and What to Do about It, Princeton University Press.

Lerner, J., 1999. The Government as Venture Capitalist: The Long-run Effects of the SBIR Program, Journal of Business 72, 285-318.

Levie, J., \& Autio, E. 2008. A theoretical grounding and test of the GEM model. Small Business Economics, 31: 235-263.

Levine, R., 2005. Finance and growth: theory and evidence, in P. Aghion and S. Durlauf, eds., Handbook of Economic Growth, Elsevier.

Li, W., 2002. Entrepreneurship and government subsidies: A general equilibrium analysis, Journal of Economic Dynamics and Control 26, 1815-1844.

Manso, G., 2011. Motivating innovation, Journal of Finance 66, 1823-1869.

North, D., 1990. Institutions, Institutional Change and Economic Performance. Cambridge University Press.

Organization for Economic Corporation and Development (OECD), 1996. Government Programmes for Venture Capital. Paris: OECD. 
Pettit, C. A. and Platte V. D.,2011. Homestead Exemptions in Bankruptcy After the Bankruptcy Abuse Prevention and Consumer Protection Act of 2005 (BAPCPA). Congressional Research Service.

Saint-Paul, G., 1997. Is labor rigidity harming Europe's competitiveness?, European Economic Review 41, 499-506.

Saint-Paul, G., 2002a. Employment protection, international specialization, and innovation, European Economic Review 46, 375-395.

Samaniego, R. 2006, Employment protection and high-tech aversion., Review of Economic Dynamics 9, 224-241.

Schumpeter, J.A., 1934. The theory of economic development. Harvard University Press.

Sobel, R.S., 2008. Economic freedom, entrepreneurship, and economic growth at the subnational level, in Karabegovic, A., and F. McMahon, eds., Economic Freedom in North America. Vancouver: The Fraser Institute.

Thurik, A.R., M.A. Carree, A. van Stel, and D.B. Audretsch, 2008. Does self-employment reduce unemployment? Journal of Business Venturing 23, 673-686.

Ueda, M. and M. Hirukawa, 2008. Venture Capital and Innovation: Which is First? Working Paper, University of Wisconsin, Madison.

Wang, S., and S. Wang, 2010. Cross-border venture capital performance: Evidence from China. Pacific-Basin Finance Journal 19, 71-97.

Wang, L., and S. Wang, 2012a. Endogenous networks in investment syndication, Journal of Corporate Finance, 18, 640-663

Wang, L., and S. Wang, 2012b. Economic freedom and cross-border venture capital performance, Journal of Empirical Finance, forthcoming.

Wang, S., and H. Zhou, 2004. Staged financing in venture capital: Moral hazard and risks, Journal of Corporate Finance 10, 131-155

World Bank, 2004. World Bank Group Support for Small Business. Washington, DC: World Bank.

World Bank, 2002. World Bank Group Review of Small Business Activities. Washington, DC: World Bank.

World Bank, 1994. Can Intervention Work? The Role of Government in SME Success. Washington, DC: World Bank.

Xue, J., and P.G. Klein, 2010. Regional determinants of technology entrepreneurship, International Journal of Entrepreneurial Venturing, 291-308.

Yung, C., 2009. Entrepreneurial financing and costly due diligence, Financial Review, 44, 137-149. 
Table 1. Variable Definitions and Summary Statistics for Control Variables

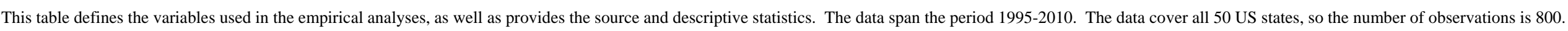

\begin{tabular}{|c|c|c|c|c|c|c|c|c|}
\hline Variable & Definition & Source & Obs & Mean & Std Dev & Min & Median & Max \\
\hline \multicolumn{9}{|c|}{ Dependent Variable } \\
\hline births_pop1 & $\begin{array}{l}\text { The U.S. establishment births per } 1000000 \text { population of year } \mathrm{t} / \mathrm{t}+1 \text { is the numbers } \\
\text { of physical locations, where business is conducted, or services or industrial } \\
\text { operations are performed, which have zero employment in the first quarter of year } \mathrm{t} \\
\text { and } 1 \text { to } 4 \text { employment in the first quarter of year } \mathrm{t}+1 \text {. }\end{array}$ & http://www.census.gov & 800 & $1,648.48$ & 410.95 & 762.01 & $1,576.28$ & $3,284.88$ \\
\hline births_pop2 & $\begin{array}{l}\text { The U.S. establishment births per } 1000000 \text { population of year } \mathrm{t} / \mathrm{t}+1 \text { is the numbers } \\
\text { of physical locations, where business is conducted, or services or industrial } \\
\text { operations are performed, which have zero employment in the first quarter of year } \mathrm{t} \\
\text { and } 5 \text { to } 9 \text { employment in the first quarter of year } \mathrm{t}+1 \text {. }\end{array}$ & http://www.census.gov & 800 & 262.59 & 85.70 & 104.69 & 266.84 & 549.11 \\
\hline births_pop3 & $\begin{array}{l}\text { The U.S. establishment births per } 1000000 \text { population of year } \mathrm{t} / \mathrm{t}+1 \text { is the numbers } \\
\text { of physical locations, where business is conducted, or services or industrial } \\
\text { operations are performed, which have zero employment in the first quarter of year } \mathrm{t} \\
\text { and } 10 \text { to } 19 \text { employment in the first quarter of year } \mathrm{t}+1 \text {. }\end{array}$ & http://www.census.gov & 800 & 147.11 & 38.53 & 79.68 & 137.58 & 320.47 \\
\hline birth_rate1 & $\begin{array}{l}\text { The U.S. establishment birth rate of year } \mathrm{t} / \mathrm{t}+1 \text { is the US establishment births for size } \\
1-4 \text { of year } \mathrm{t} / \mathrm{t}+1 \text { divided by the US initial year establishments for size } 1-4 \text {. }\end{array}$ & http://www.census.gov & 800 & $16.39 \%$ & $2.81 \%$ & $10.28 \%$ & $15.94 \%$ & $27.46 \%$ \\
\hline birth_rate2 & $\begin{array}{l}\text { The U.S. establishment birth rate of year } t / t+1 \text { is the US establishment births for size } \\
5-9 \text { of year } t / t+1 \text { divided by the US initial year establishments for size 5-9. }\end{array}$ & http://www.census.gov & 800 & $6.84 \%$ & $2.16 \%$ & $2.63 \%$ & $6.84 \%$ & $15.81 \%$ \\
\hline birth_rate3 & $\begin{array}{l}\text { The U.S. establishment birth rate of year } \mathrm{t} / \mathrm{t}+1 \text { is the US establishment births for size } \\
10-19 \text { of year } \mathrm{t} / \mathrm{t}+1 \text { divided by the US initial year establishments for size } 10-19 \text {. }\end{array}$ & http://www.census.gov & 800 & $6.12 \%$ & $1.59 \%$ & $3.35 \%$ & $5.75 \%$ & $12.78 \%$ \\
\hline Net_Change_pop1 & $\begin{array}{l}\text { The U.S. establishment change per } 1000000 \text { population for size } 1-4 \text { of year } t / t+1 \text { is } \\
\text { the difference of the total establishment for size } 1-4 \text { of year } t+1 \text { and year } t \text {. }\end{array}$ & http://www.census.gov & 800 & 83.91 & 275.04 & -1114.63 & 104.05 & 1058.33 \\
\hline Net_Change_pop2 & $\begin{array}{l}\text { The U.S. establishment change per } 1000000 \text { population for size } 5-9 \text { of year } t / t+1 \text { is } \\
\text { the difference of the total establishment for size } 5-9 \text { of year } t+1 \text { and year } t \text {. }\end{array}$ & http://www.census.gov & 800 & 17.95 & 44.04 & -136.50 & 17.94 & 187.17 \\
\hline Net_Change_pop3 & $\begin{array}{l}\text { The U.S. establishment change per } 1000000 \text { population for size } 10-19 \text { of year } t / t+1 \\
\text { is the difference of the total establishment for size } 10-19 \text { of year } t+1 \text { and year } t \text {. }\end{array}$ & http://www.census.gov & 800 & 4.13 & 24.53 & -87.64 & 2.30 & 122.91 \\
\hline Net_rate1 & $\begin{array}{l}\text { The U.S. net establishment rate of change for size } 1-4 \text { of year } \mathrm{t} / \mathrm{t}+1 \text { is the US } \\
\text { establishment change for size } 1-4 \text { of year } \mathrm{t} / \mathrm{t}+1 \text { divided by the US initial year } \\
\text { establishments for size } 1-4 \text {. }\end{array}$ & http://www.census.gov & 800 & $0.79 \%$ & $2.68 \%$ & $-9.16 \%$ & $1.02 \%$ & $9.80 \%$ \\
\hline Net_rate2 & $\begin{array}{l}\text { The U.S. net establishment rate of change for size } 5-9 \text { of year } t / t+1 \text { is the US } \\
\text { establishment change for size } 5-9 \text { of year } t / t+1 \text { divided by the US initial year } \\
\text { establishments for size 5-9. }\end{array}$ & http://www.census.gov & 800 & $0.47 \%$ & $1.17 \%$ & $-3.49 \%$ & $0.45 \%$ & $5.37 \%$ \\
\hline Net_rate3 & $\begin{array}{l}\text { The U.S. net establishment rate of change for size } 10-19 \text { of year } \mathrm{t} / \mathrm{t}+1 \text { is the US } \\
\text { establishment change for size } 10-19 \text { of year } \mathrm{t} / \mathrm{t}+1 \text { divided by the US initial year } \\
\text { establishments for size } 10-19 \text {. }\end{array}$ & http://www.census.gov & 800 & $0.17 \%$ & $0.99 \%$ & $-3.17 \%$ & $0.10 \%$ & $3.88 \%$ \\
\hline
\end{tabular}




\begin{tabular}{|c|c|c|c|c|c|c|c|c|}
\hline Variable & Definition & Source & Obs & Mean & Std Dev & Min & Median & Max \\
\hline \multicolumn{9}{|c|}{ Independent Variables } \\
\hline $\begin{array}{l}\text { Size of Gov. Index, Combining } \\
1 \mathrm{~A} / 1 \mathrm{~B} / 1 \mathrm{C}\end{array}$ & $\begin{array}{c}\text { The index measures the government intervention in the economy as an equal- } \\
\text { weighted average of its three components: size_of_gov_1A, size_of_gov_1B and } \\
\text { size_of_gov_1C. The index has a scale from } 0 \text { to } 10 \text {, with a high score indicating a } \\
\text { higher degree of economic freedom. }\end{array}$ & $\begin{array}{l}\text { http://www.freetheworl } \\
\text { d.com }\end{array}$ & 800 & 7.02 & 0.96 & 2.49 & 7.10 & 9.10 \\
\hline $\begin{array}{l}\text { Size of Gov. Index_1A: Gov } \\
\text { Consumption/GDP }\end{array}$ & $\begin{array}{l}\text { This index measures the general consumption expenditures by government as a } \\
\text { percentage of GDP. It decreases in government spending. The index ranges from } \\
\text { zero to } 10 \text { with a high score indicating a higher degree of economic freedom. }\end{array}$ & $\begin{array}{l}\text { http://www.freetheworl } \\
\text { d.com }\end{array}$ & 800 & 7.16 & 1.30 & 1.93 & 7.41 & 10.00 \\
\hline $\begin{array}{l}\text { Size of Gov. Index_1B: } \\
\text { Transfers\&Subsidies/GDP }\end{array}$ & $\begin{array}{c}\text { This index measures the transfers and subsidies as a percentage of GDP. The index } \\
\text { ranges from zero to } 10 \text { with a high score indicating a higher degree of economic } \\
\text { freedom. The greater the level of transfers and subsidies, the lower the score a } \\
\text { jurisdiction receives. }\end{array}$ & $\begin{array}{l}\text { http://www.freetheworl } \\
\text { d.com }\end{array}$ & 800 & 8.39 & 0.96 & 1.37 & 8.63 & 9.89 \\
\hline $\begin{array}{l}\text { Size of Gov. Index_1C: Social } \\
\text { Security Payments/GDP }\end{array}$ & $\begin{array}{l}\text { This index measures the social security payments as a percentage of GDP. The } \\
\text { higher the payment, the lower the index. The index ranges from zero to } 10 \text { with a } \\
\text { high score indicating a higher degree of economic freedom. }\end{array}$ & $\begin{array}{l}\text { http://www.freetheworl } \\
\text { d.com }\end{array}$ & 800 & 5.52 & 1.21 & 0.00 & 5.73 & 7.84 \\
\hline $\begin{array}{l}\text { Takings and Dis. Tax Index, } \\
\text { Combining } 2 \mathrm{~A} / 2 \mathrm{~B} / 2 \mathrm{C}\end{array}$ & $\begin{array}{l}\text { The index measures the government intervention in the economy as an equal- } \\
\text { weighted average of its three components: Takeings_and_Discim_Tax_2A, } \\
\text { Takeings_and_Discim_Tax_2B and Takeings_and_Discim_Tax_2C. The index has } \\
\text { a scale from } 0 \text { to } 10 \text {, with a high score indicating a higher degree of economic } \\
\text { freedom. }\end{array}$ & $\begin{array}{l}\text { http://www.freetheworl } \\
\text { d.com }\end{array}$ & 800 & 5.92 & 0.77 & 3.54 & 5.95 & 8.60 \\
\hline $\begin{array}{c}\text { Takings and Dis. Tax } \\
\text { Index_2A:Tax Revenue/GDP }\end{array}$ & $\begin{array}{l}\text { This index measures the total tax revenues as a percentage of GDP. The higher the } \\
\text { percentage the lower the index. The index ranges from zero to } 10 \text { with a high score } \\
\text { indicating a higher degree of economic freedom. }\end{array}$ & $\begin{array}{l}\text { http://www.freetheworl } \\
\text { d.com }\end{array}$ & 800 & 5.82 & 1.23 & 1.83 & 5.86 & 10.00 \\
\hline $\begin{array}{l}\text { Takings and Dis. Tax } \\
\text { Index_2B:Top Marginal } \\
\text { Income Tax Rate }\end{array}$ & $\begin{array}{c}\text { This index measures the top marginal income tax rate and the income threshold as a } \\
\text { percentage of GDP. The higher the percentage, the lower the index. The index } \\
\text { ranges from zero to } 10 \text { with a high score indicating a higher degree of economic } \\
\text { freedom. }\end{array}$ & $\begin{array}{l}\text { http://www.freetheworl } \\
\text { d.com }\end{array}$ & 800 & 5.38 & 1.31 & 3.00 & 5.00 & 8.00 \\
\hline $\begin{array}{l}\text { Takings and Dis. Tax } \\
\text { Index_2C:Indirect Tax } \\
\quad \text { Revenue/GDP }\end{array}$ & $\begin{array}{l}\text { This index measures the Indirect tax revenue as a percentage of GDP. The higher the } \\
\text { percentage, the lower the index. The index ranges from zero to } 10 \text { with a high score } \\
\text { indicating a higher degree of economic freedom. }\end{array}$ & $\begin{array}{l}\text { http://www.freetheworl } \\
\text { d.com }\end{array}$ & 800 & 5.07 & 1.46 & 0.00 & 5.30 & 9.03 \\
\hline$\underset{\text { Dakeings_and_Discim_Tax_2 }}{\text { D }}$ & $\begin{array}{l}\text { This index measures the sales taxes collected as a percentage of GDP. The higher } \\
\text { the percentage, the lower the index. The index ranges from zero to } 10 \text { with a high } \\
\text { score indicating a higher degree of economic freedom. }\end{array}$ & $\begin{array}{l}\text { http://www.freetheworl } \\
\text { d.com }\end{array}$ & 800 & 7.40 & 1.04 & 4.48 & 7.40 & 9.85 \\
\hline $\begin{array}{l}\text { Labor Freedom Index, } \\
\text { Combining 3A/3B/3C }\end{array}$ & $\begin{array}{l}\text { The index measures the general labor freedom as an equal-weighted average of its } \\
\text { three components: labor_freedom_3A, labor_freedom_3B andlabor_freedom_3C. } \\
\text { The index has a scale from } 0 \text { to } 10 \text {, with a high score indicating a higher degree of } \\
\text { economic freedom. }\end{array}$ & $\begin{array}{l}\text { http://www.freetheworl } \\
\text { d.com }\end{array}$ & 800 & 7.12 & 0.56 & 5.50 & 7.10 & 8.42 \\
\hline
\end{tabular}




\begin{tabular}{|c|c|c|c|c|c|c|c|c|}
\hline Variable & Definition & Source & Obs & Mean & Std Dev & Min & Median & Max \\
\hline $\begin{array}{l}\text { Labor Freedom Index_3A: Min } \\
\text { Wage Legislation }\end{array}$ & $\begin{array}{l}\text { This index measures the minimum wage legislation, calculated as the annual income } \\
\text { earned by someone working at the minimum wage as a ratio of per-capita GDP. The } \\
\text { higher the ratio, the lower the index. The index ranges from zero to } 10 \text { with a high } \\
\text { score indicating a higher degree of economic freedom. }\end{array}$ & $\begin{array}{l}\text { http://www.freetheworl } \\
\text { d.com }\end{array}$ & 800 & 7.20 & 0.93 & 4.56 & 7.23 & 9.65 \\
\hline $\begin{array}{l}\text { Labor Freedom Index_3B: Gov. } \\
\text { Employment/Total Employment }\end{array}$ & $\begin{array}{l}\text { This index measures the government employment as a percentage of total state } \\
\text { employment. The higher the percentage, the lower the index. The index ranges from } \\
\text { zero to } 10 \text { with a high score indicating a higher degree of economic freedom. }\end{array}$ & $\begin{array}{l}\text { http://www.freetheworl } \\
\text { d.com }\end{array}$ & 800 & 7.55 & 1.35 & 3.07 & 7.84 & 9.80 \\
\hline $\begin{array}{l}\text { Labor Freedom Index_3C: } \\
\text { Union Density }\end{array}$ & $\begin{array}{l}\text { This index measures the union density, calculated as the percentage of unionized } \\
\text { workers in a state after adjusting the influence of government employment, the size } \\
\text { of the manufacturing sector and size of the rural population. The higher the ratio, the } \\
\text { lower the index. The index ranges from zero to } 10 \text { with a high score indicating a } \\
\text { higher degree of economic freedom. }\end{array}$ & $\begin{array}{l}\text { http://www.freetheworl } \\
\text { d.com }\end{array}$ & 800 & 6.61 & 1.75 & 2.49 & 6.72 & 10.00 \\
\hline $\begin{array}{c}\text { Difference Corporate - Income } \\
\text { Taxes }\end{array}$ & The difference between corporate and individual top marginal income tax rate & $\begin{array}{l}\text { http://www.taxfoundatio } \\
\text { n.org }\end{array}$ & 800 & $-1.58 \%$ & $3.52 \%$ & $-9.78 \%$ & $-1.83 \%$ & $9.40 \%$ \\
\hline Patent_pop & $\begin{array}{c}\text { Number of utility patents per } 1000 \text { population granted by the U.S. Patent and } \\
\text { Trademark Office }\end{array}$ & http://www.uspto.gov/ & 800 & 0.24 & 0.19 & 0.03 & 0.20 & 1.36 \\
\hline Real GDP / Population & Real GDP (in millions of 2000 dollars) per 1000 people & http://www.bea.gov & 800 & 33.87 & 6.79 & 21.45 & 32.80 & 60.58 \\
\hline Homestead Exemption & $\begin{array}{l}\text { The bankrupcy examption for equity in owner-occupied principal residences. If a } \\
\text { state had an unlimited homestead exemption, following the methodology in } \\
\text { Berkowitz and White, it was given a value of } \$ 160,000 \text {. }\end{array}$ & $\begin{array}{l}\text { Berkowitz and White } \\
\text { (2004), Fan and White } \\
\text { (2003), Pettit and Platte } \\
\text { (2011) }\end{array}$ & 800 & 62,012 & 70,533 & 0 & 33,813 & 455,220 \\
\hline $\begin{array}{l}\text { Unlimited_Homestead_Exempti } \\
\text { on }\end{array}$ & A dummy variable equal to 1 for a state with an unlimited homestead exemption. & $\begin{array}{l}\text { http://www.ssti.org/Dig } \\
\text { est/Indices/usefulstats.ht } \\
\text { m }\end{array}$ & 800 & 0.14 & 0.35 & 0 & 0 & 1.00 \\
\hline Education & $\begin{array}{c}\text { Fraction of persons } 25 \text { years old and over with a bachelor's degree or more (in } \\
\text { percentage) }\end{array}$ & http://www.bea.gov & 800 & 22.15 & 9.52 & 0.00 & 24.20 & 40.40 \\
\hline pi_growth & Growth rate of personal income (in percentage) & http://www.bea.gov & 800 & -0.14 & 3.54 & -47.03 & -0.11 & 73.11 \\
\hline No_NBIA & Number of business incubators per 1 million people & $\begin{array}{l}\text { http://www.nbia.org/lin } \\
\text { ks_to_member_incubato } \\
\text { rs/index.php }\end{array}$ & 800 & 0.91 & 0.76 & 0.00 & 0.77 & 4.72 \\
\hline NBIA & Dummy variable set to 1 in a year when this exists at least one business incubator & http://www.nbia.org & 800 & 0.75 & 0.44 & 0.00 & 1.00 & 1.00 \\
\hline Academic R\&D & Academic science and engineering R\&D per $\$ 1,000$ of GDP & http://www.ssti.org & 800 & 637,605 & 834,308 & 0.00 & 375,611 & $5,967,396$ \\
\hline VCN_pop & Number of venture capital deal per 1 million people & $\begin{array}{l}\text { https://www.pwcmoneyt } \\
\text { ree.com/MTPublic/ns/in } \\
\text { dex.jsp }\end{array}$ & 800 & 8.21 & 12.13 & 0.00 & 4.00 & 122.11 \\
\hline
\end{tabular}




\section{Table 2: Comparison Tests}

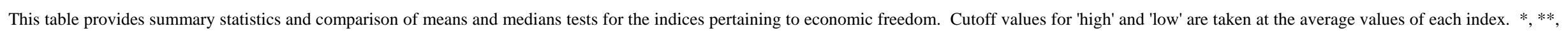
*** Statistically significant at the $10 \%, 5 \%$ and $1 \%$ levels, respectively.

\section{Panel A. U.S. Establishment Births per 1 million population}

\begin{tabular}{|c|c|c|c|c|c|c|c|c|c|c|c|c|c|c|c|c|c|c|}
\hline & \multicolumn{6}{|c|}{$\begin{array}{l}\text { U.S. Establishment Births per } 1 \text { million population for Firm } \\
\text { Size 1-4 }\end{array}$} & \multicolumn{6}{|c|}{$\begin{array}{l}\text { U.S. Establishment Births per } 1 \text { million population for } \\
\text { Firm Size 5-9 }\end{array}$} & \multicolumn{6}{|c|}{$\begin{array}{l}\text { U.S. Establishment Births per } 1 \text { million population for Firm } \\
\text { Size 10-19 }\end{array}$} \\
\hline & \multicolumn{2}{|c|}{ Size of Gov. Index } & \multicolumn{2}{|c|}{$\begin{array}{l}\text { Takings and Dis. Tax } \\
\text { Index }\end{array}$} & \multicolumn{2}{|c|}{$\begin{array}{l}\text { Labor Freedom } \\
\text { Index }\end{array}$} & \multicolumn{2}{|c|}{$\begin{array}{l}\text { Size of Gov. } \\
\text { Index }\end{array}$} & \multicolumn{2}{|c|}{$\begin{array}{l}\text { Takings and Dis. } \\
\text { Tax Index }\end{array}$} & \multicolumn{2}{|c|}{$\begin{array}{l}\text { Labor Freedom } \\
\text { Index }\end{array}$} & \multicolumn{2}{|c|}{ Size of Gov. Index } & \multicolumn{2}{|c|}{$\begin{array}{l}\text { Takings and Dis. } \\
\text { Tax Index }\end{array}$} & \multicolumn{2}{|c|}{$\begin{array}{l}\text { Labor Freedom } \\
\text { Index }\end{array}$} \\
\hline & Low & High & Low & High & Low & High & Low & High & Low & High & Low & High & Low & High & Low & High & Low & High \\
\hline No. of Obs. & 407 & 393 & 400 & 400 & 411 & 389 & 407 & 393 & 400 & 400 & 411 & 389 & 407 & 393 & 400 & 400 & 411 & 389 \\
\hline Mean & 1595 & 1704 & 1675 & 1622 & 1621 & 1677 & 255 & 271 & 281 & 245 & 278 & 246 & 141 & 153 & 147 & 147 & 143 & 151 \\
\hline Std.Dev & 449 & 360 & 405 & 416 & 408 & 412 & 85 & 86 & 82 & 86 & 78 & 90 & 36 & 40 & 39 & 38 & 39 & 37 \\
\hline Median & 1503 & 1642 & 1601 & 1555 & 1544 & 1595 & 256 & 272 & 279 & 245 & 275 & 247 & 131 & 144 & 136 & 139 & 131 & 144 \\
\hline $\begin{array}{l}\text { Diff. in } \\
\text { Means }\end{array}$ & 109.20 & $* * *$ & -53.26 & * & 56.26 & $*$ & 15.84 & $* * *$ & -35.93 & $* * *$ & -31.90 & $* * *$ & 12.40 & $* * *$ & 0.40 & & 8.46 & $* * *$ \\
\hline $\begin{array}{l}\text { Diff in } \\
\text { Medians }\end{array}$ & 139.00 & $* * *$ & -46.11 & $* *$ & 50.37 & $*$ & 15.54 & $* * *$ & -33.52 & $* * *$ & -27.16 & $* * *$ & 13.37 & $* * *$ & 2.51 & & 13.25 & $* * *$ \\
\hline
\end{tabular}

\section{Panel B. U.S. Establishment Birth Rate}

\begin{tabular}{|c|c|c|c|c|c|c|c|c|c|c|c|c|c|c|c|c|c|c|}
\hline & \multicolumn{6}{|c|}{ U.S. Establishment Birth Rate for Firm Size 1-4 } & \multicolumn{6}{|c|}{ U.S. Establishment Birth Rate for Firm Size 5-9 } & \multicolumn{6}{|c|}{ U.S. Establishment Birth Rate for Firm Size 10-19 } \\
\hline & \multicolumn{2}{|c|}{ Size of Gov. Index } & \multicolumn{2}{|c|}{$\begin{array}{c}\text { Takings and Dis. Tax } \\
\text { Index }\end{array}$} & \multicolumn{2}{|c|}{$\begin{array}{c}\text { Labor Freedom } \\
\text { Index } \\
\end{array}$} & \multicolumn{2}{|c|}{$\begin{array}{l}\text { Size of Gov. } \\
\text { Index }\end{array}$} & \multicolumn{2}{|c|}{$\begin{array}{l}\text { Takings and Dis. } \\
\text { Tax Index } \\
\end{array}$} & \multicolumn{2}{|c|}{$\begin{array}{l}\text { Labor Freedom } \\
\text { Index } \\
\end{array}$} & \multicolumn{2}{|c|}{ Size of Gov. Index } & \multicolumn{2}{|c|}{$\begin{array}{l}\text { Takings and Dis. } \\
\text { Tax Index }\end{array}$} & \multicolumn{2}{|c|}{$\begin{array}{c}\text { Labor Freedom } \\
\text { Index }\end{array}$} \\
\hline & Low & High & Low & High & Low & High & Low & High & Low & High & Low & High & Low & High & Low & High & Low & High \\
\hline No. of Obs. & 407 & 393 & 400 & 400 & 411 & 389 & 407 & 393 & 400 & 400 & 411 & 389 & 407 & 393 & 400 & 400 & 411 & 389 \\
\hline Mean & $15.75 \%$ & $17.05 \%$ & $16.07 \%$ & $16.71 \%$ & $15.89 \%$ & $16.92 \%$ & $6.55 \%$ & $7.14 \%$ & $7.12 \%$ & $6.56 \%$ & $7.09 \%$ & $6.57 \%$ & $5.86 \%$ & $6.39 \%$ & $6.02 \%$ & $6.22 \%$ & $5.84 \%$ & $6.41 \%$ \\
\hline Std.Dev & $2.44 \%$ & $3.01 \%$ & $2.60 \%$ & $2.97 \%$ & $2.49 \%$ & $3.02 \%$ & $1.89 \%$ & $2.38 \%$ & $2.00 \%$ & $2.28 \%$ & $1.84 \%$ & $2.43 \%$ & $1.34 \%$ & $1.78 \%$ & $1.59 \%$ & $1.60 \%$ & $1.46 \%$ & $1.68 \%$ \\
\hline Median & $15.59 \%$ & $16.45 \%$ & $15.80 \%$ & $16.08 \%$ & $15.62 \%$ & $16.48 \%$ & $6.71 \%$ & $6.95 \%$ & $6.99 \%$ & $6.61 \%$ & $7.07 \%$ & $6.39 \%$ & $5.65 \%$ & $5.94 \%$ & $5.63 \%$ & $5.88 \%$ & $5.53 \%$ & $6.14 \%$ \\
\hline $\begin{array}{l}\text { Diff. in } \\
\text { Means }\end{array}$ & $1.31 \%$ & $* * *$ & $0.64 \%$ & $* * *$ & $1.03 \%$ & $* * *$ & $0.60 \%$ & $* * *$ & $-0.56 \%$ & $* * *$ & $-0.53 \%$ & $* * *$ & $0.53 \%$ & $* * *$ & $0.20 \%$ & * & $0.57 \%$ & $* * *$ \\
\hline $\begin{array}{l}\text { Diff in } \\
\text { Medians }\end{array}$ & $0.86 \%$ & $* * *$ & $0.28 \%$ & $* * *$ & $0.86 \%$ & $* * *$ & $0.25 \%$ & $* * *$ & $-0.39 \%$ & $* * *$ & $-0.68 \%$ & $* * *$ & $0.29 \%$ & $* * *$ & $0.25 \%$ & $* *$ & $0.61 \%$ & $* * *$ \\
\hline
\end{tabular}




\begin{tabular}{|c|c|c|c|c|c|c|c|c|c|c|c|c|c|c|c|c|c|c|}
\hline \multicolumn{19}{|c|}{ Panel C. U.S. Establishment Net Change (Births - Deaths) per 1000 population } \\
\hline & \multicolumn{6}{|c|}{$\begin{array}{l}\text { U.S. Establishment Change per } 1 \text { million population for Firm } \\
\text { Size 1-4 }\end{array}$} & \multicolumn{6}{|c|}{$\begin{array}{l}\text { U.S. Establishment Change per } 1 \text { million population for } \\
\text { Firm Size 5-9 }\end{array}$} & \multicolumn{6}{|c|}{$\begin{array}{l}\text { U.S. Establishment Change per } 1 \text { million population for } \\
\text { Firm Size 10-19 }\end{array}$} \\
\hline & \multicolumn{2}{|c|}{ Size of Gov. Index } & \multicolumn{2}{|c|}{$\begin{array}{l}\text { Takings and Dis. Tax } \\
\text { Index }\end{array}$} & \multicolumn{2}{|c|}{$\begin{array}{l}\text { Labor Freedom } \\
\text { Index }\end{array}$} & \multicolumn{2}{|c|}{$\begin{array}{l}\text { Size of Gov. } \\
\text { Index } \\
\end{array}$} & \multicolumn{2}{|c|}{$\begin{array}{l}\text { Takings and Dis. } \\
\text { Tax Index } \\
\end{array}$} & \multicolumn{2}{|c|}{$\begin{array}{l}\text { Labor Freedom } \\
\text { Index }\end{array}$} & \multicolumn{2}{|c|}{ Size of Gov. Index } & \multicolumn{2}{|c|}{$\begin{array}{l}\text { Takings and Dis. } \\
\text { Tax Index } \\
\end{array}$} & \multicolumn{2}{|c|}{\begin{tabular}{|c|}
$\begin{array}{c}\text { Labor Freedom } \\
\text { Index }\end{array}$ \\
\end{tabular}} \\
\hline & Low & High & Low & High & Low & High & Low & High & Low & High & Low & High & Low & High & Low & High & Low & High \\
\hline No. of Obs. & 407 & 393 & 400 & 400 & 411 & 389 & 407 & 393 & 400 & 400 & 411 & 389 & 407 & 393 & 400 & 400 & 411 & 389 \\
\hline Mean & 36.7 & 132.8 & 87.7 & 80.2 & 64.0 & 105.0 & 11.4 & 24.7 & 16.5 & 19.4 & 13.6 & 22.5 & 2.8 & 5.5 & 0.5 & 7.7 & 0.5 & 7.9 \\
\hline Std.Dev & 290.5 & 249.2 & 252.7 & 296.0 & 254.5 & 294.0 & 46.3 & 40.6 & 41.6 & 46.4 & 42.0 & 45.7 & 24.7 & 24.4 & 23.1 & 25.4 & 24.0 & 24.6 \\
\hline Median & 55.2 & 130.6 & 111.9 & 92.5 & 86.1 & 118.3 & 13.4 & 21.1 & 15.3 & 20.3 & 14.9 & 22.0 & 3.3 & 1.7 & -1.2 & 6.1 & -1.4 & 6.8 \\
\hline $\begin{array}{l}\text { Diff. in } \\
\text { Means }\end{array}$ & 96.06 & $* * *$ & -7.50 & & 40.99 & $* *$ & 13.35 & $* * *$ & 2.85 & & 8.85 & $* * *$ & 2.71 & & 7.21 & $* * *$ & 7.42 & $* * *$ \\
\hline $\begin{array}{c}\text { Diff in } \\
\text { Medians }\end{array}$ & 75.38 & $* * *$ & -19.40 & & 32.14 & $* *$ & 7.71 & $* * *$ & 4.97 & & 7.05 & $* * *$ & -1.69 & & 7.26 & $* * *$ & 8.27 & $* * *$ \\
\hline \multicolumn{19}{|c|}{ Panel D. U.S. Establishment Net Rate of Change (Births - Deaths) } \\
\hline & \multicolumn{6}{|c|}{ U.S. Establishment Rate of Change for Firm Size 1-4 } & \multicolumn{6}{|c|}{ U.S. Establishment Rate of Change for Firm Size 5-9 } & \multicolumn{6}{|c|}{ U.S. Establishment Rate of Change for Firm Size 10-19 } \\
\hline & \multicolumn{2}{|c|}{ Size of Gov. Index } & \multicolumn{2}{|c|}{$\begin{array}{c}\text { Takings and Dis. Tax } \\
\text { Index } \\
\end{array}$} & \multicolumn{2}{|c|}{$\begin{array}{c}\text { Labor Freedom } \\
\text { Index }\end{array}$} & \multicolumn{2}{|c|}{$\begin{array}{l}\text { Size of Gov. } \\
\text { Index }\end{array}$} & \multicolumn{2}{|c|}{$\begin{array}{c}\text { Takings and Dis. } \\
\text { Tax Index }\end{array}$} & \multicolumn{2}{|c|}{$\begin{array}{l}\text { Labor Freedom } \\
\text { Index } \\
\end{array}$} & \multicolumn{2}{|c|}{ Size of Gov. Index } & \multicolumn{2}{|c|}{$\begin{array}{c}\text { Takings and Dis. } \\
\text { Tax Index } \\
\end{array}$} & \multicolumn{2}{|c|}{$\begin{array}{c}\begin{array}{c}\text { Labor Freedom } \\
\text { Index }\end{array} \\
\end{array}$} \\
\hline & Low & High & Low & High & Low & High & Low & High & Low & High & Low & High & Low & High & Low & High & Low & High \\
\hline No. of Obs. & 407 & 393 & 400 & 400 & 411 & 389 & 407 & 393 & 400 & 400 & 411 & 389 & 407 & 393 & 400 & 400 & 411 & 389 \\
\hline Mean & $0.24 \%$ & $1.35 \%$ & $0.80 \%$ & $0.77 \%$ & $0.57 \%$ & $1.02 \%$ & $0.27 \%$ & $0.68 \%$ & $0.42 \%$ & $0.52 \%$ & $0.34 \%$ & $0.60 \%$ & $0.11 \%$ & $0.24 \%$ & $0.02 \%$ & $0.32 \%$ & $0.02 \%$ & $0.34 \%$ \\
\hline Std.Dev & $2.75 \%$ & $2.49 \%$ & $2.33 \%$ & $2.99 \%$ & $2.41 \%$ & $2.93 \%$ & $1.17 \%$ & $1.13 \%$ & $1.05 \%$ & $1.27 \%$ & $1.07 \%$ & $1.25 \%$ & $0.97 \%$ & $1.00 \%$ & $0.90 \%$ & $1.04 \%$ & $0.90 \%$ & $1.04 \%$ \\
\hline Median & $0.60 \%$ & $1.31 \%$ & $1.06 \%$ & $1.00 \%$ & $0.81 \%$ & $1.20 \%$ & $0.36 \%$ & $0.53 \%$ & $0.40 \%$ & $0.53 \%$ & $0.39 \%$ & $0.54 \%$ & $0.14 \%$ & $0.07 \%$ & $-0.05 \%$ & $0.25 \%$ & $-0.06 \%$ & $0.30 \%$ \\
\hline $\begin{array}{l}\text { Diff. in } \\
\text { Means }\end{array}$ & $1.11 \%$ & $* * *$ & $-0.03 \%$ & & $0.46 \%$ & $* *$ & $0.41 \%$ & $* * *$ & $0.10 \%$ & & $0.26 \%$ & $* * *$ & $0.14 \%$ & $*$ & $0.30 \%$ & $* * *$ & $0.32 \%$ & $* * *$ \\
\hline $\begin{array}{l}\text { Diff in } \\
\text { Medians }\end{array}$ & $0.72 \%$ & $* * *$ & $-0.06 \%$ & & $0.39 \%$ & $* *$ & $0.18 \%$ & $* * *$ & $0.13 \%$ & * & $0.14 \%$ & $* * *$ & $-0.08 \%$ & & $0.30 \%$ & $* * *$ & $0.36 \%$ & $* * *$ \\
\hline
\end{tabular}




\begin{tabular}{|c|c|c|c|c|c|c|c|c|c|c|c|c|c|c|c|c|c|c|}
\hline & \multicolumn{6}{|c|}{ Venture Capital Deals per 1 million people } & \multicolumn{6}{|c|}{ Venture Capital Dollars per 1,000 people } & \multicolumn{6}{|c|}{ Patents per 1,000 people } \\
\hline & \multicolumn{2}{|c|}{ Size of Gov. Index } & \multicolumn{2}{|c|}{$\begin{array}{l}\text { Takings and Dis. Tax } \\
\text { Index }\end{array}$} & \multicolumn{2}{|c|}{$\begin{array}{l}\text { Labor Freedom } \\
\text { Index }\end{array}$} & \multicolumn{2}{|c|}{$\begin{array}{l}\text { Size of Gov. } \\
\text { Index }\end{array}$} & \multicolumn{2}{|c|}{$\begin{array}{l}\text { Takings and Dis. } \\
\text { Tax Index }\end{array}$} & \multicolumn{2}{|c|}{$\begin{array}{l}\text { Labor Freedom } \\
\text { Index }\end{array}$} & \multicolumn{2}{|c|}{ Size of Gov. Index } & \multicolumn{2}{|c|}{$\begin{array}{l}\text { Takings and Dis. } \\
\text { Tax Index }\end{array}$} & \multicolumn{2}{|c|}{$\begin{array}{l}\text { Labor Freedom } \\
\text { Index }\end{array}$} \\
\hline & Low & High & Low & High & Low & High & Low & High & Low & High & Low & High & Low & High & Low & High & Low & High \\
\hline No. of Obs. & 407 & 393 & 400 & 400 & 411 & 389 & 407 & 393 & 400 & 400 & 411 & 389 & 407 & 393 & 400 & 400 & 411 & 389 \\
\hline Mean & 4.28 & 12.27 & 9.21 & 7.20 & 6.980 & 9.50 & 19,687 & $\begin{array}{c}84,81 \\
9\end{array}$ & 63,684 & 39,683 & 44,582 & 59,187 & 0.19 & 0.30 & 0.25 & 0.24 & 0.25 & 0.24 \\
\hline Std.Dev & 5.56 & 15.35 & 14.01 & 9.82 & 10.550 & 13.50 & 35,096 & $\begin{array}{c}150,2 \\
29\end{array}$ & $\begin{array}{c}143,71 \\
8\end{array}$ & 67,884 & $\begin{array}{c}100,13 \\
2\end{array}$ & $\begin{array}{c}124,78 \\
5\end{array}$ & 0.21 & 0.14 & 0.21 & 0.17 & 0.20 & 0.17 \\
\hline Median & 2.47 & 7.49 & 4.06 & 3.95 & 3.320 & 5.13 & 8167 & 38575 & 16869 & 15489 & 11993 & 25801 & 0.13 & 0.28 & 0.21 & 0.19 & 0.21 & 0.18 \\
\hline $\begin{array}{l}\text { Diff. in } \\
\text { Means }\end{array}$ & 7.99 & $* * *$ & -2.01 & $* *$ & 2.52 & $* * *$ & 65,132 & $* * *$ & $-24,001$ & $* * *$ & 14,605 & * & 0.10 & $* * *$ & -0.02 & & -0.01 & \\
\hline $\begin{array}{l}\text { Diff in } \\
\text { Medians }\end{array}$ & 5.02 & $* * *$ & -0.11 & & 1.81 & $* * *$ & 30,408 & $* * *$ & $-1,380$ & & 13,808 & $* * *$ & 0.16 & $* * *$ & -0.02 & & -0.02 & \\
\hline
\end{tabular}




\begin{tabular}{|c|c|c|c|c|c|c|c|c|c|c|c|c|c|c|c|c|c|c|c|c|c|c|c|c|}
\hline \multicolumn{25}{|c|}{ This table prosents } \\
\hline \multicolumn{25}{|c|}{ Panel A. U.S. Establishment Births per 1 million population } \\
\hline & \multicolumn{8}{|c|}{ U.S. Establishment Births for Firm Size 1-4 } & \multicolumn{8}{|c|}{ U.S. Establishment Rate of Change for Firm Size 5-9 } & \multicolumn{8}{|c|}{ U.S. Establishment Rate of Change for Firm Size 10-19 } \\
\hline & \multicolumn{2}{|c|}{$\begin{array}{l}\text { Homestead } \\
\text { Exemption }\end{array}$} & \multicolumn{2}{|c|}{$\begin{array}{c}\text { Number of } \\
\text { business } \\
\text { incubators per } 1 \\
\text { million people }\end{array}$} & \multicolumn{2}{|c|}{$\begin{array}{c}\text { Academic } \\
\text { science and } \\
\text { engineering } \\
\text { R\&D per } \$ 1,000 \\
\text { of GDP }\end{array}$} & \multicolumn{2}{|c|}{$\begin{array}{l}\text { Number of } \\
\text { SBIR (Small } \\
\text { Business } \\
\text { Innovation } \\
\text { Research awards } \\
\text { per } 1 \text { million } \\
\text { people }\end{array}$} & \multicolumn{2}{|c|}{$\begin{array}{l}\text { Homestead } \\
\text { Exemption }\end{array}$} & \multicolumn{2}{|c|}{$\begin{array}{c}\text { Number of } \\
\text { business } \\
\text { incubators per } 1 \\
\text { million people }\end{array}$} & \multicolumn{2}{|c|}{$\begin{array}{c}\text { Academic } \\
\text { science and } \\
\text { engineering } \\
\text { R\&D per } \\
\$ 1,000 \text { of GDP }\end{array}$} & \multicolumn{2}{|c|}{$\begin{array}{c}\text { Number of } \\
\text { SBIR (Small } \\
\text { Business } \\
\text { Innovation } \\
\text { Research } \\
\text { awards per 1 } \\
\text { million people } \\
\end{array}$} & \multicolumn{2}{|c|}{$\begin{array}{l}\text { Homestead } \\
\text { Exemption }\end{array}$} & \multicolumn{2}{|c|}{$\begin{array}{c}\text { Number of } \\
\text { business } \\
\text { incubators per } 1 \\
\text { million people }\end{array}$} & \multicolumn{2}{|c|}{$\begin{array}{c}\text { Academic } \\
\text { science and } \\
\text { engineering } \\
\text { R\&D per } \\
\$ 1,000 \text { of GDP }\end{array}$} & \multicolumn{2}{|c|}{$\begin{array}{c}\text { Number of } \\
\text { SBIR (Small } \\
\text { Business } \\
\text { Innovation } \\
\text { Research awards } \\
\text { per } 1 \text { million } \\
\text { people }\end{array}$} \\
\hline & Low & High & Low & High & Low & High & Low & High & Low & High & Low & High & Low & High & Low & High & Low & High & Low & High & Low & High & Low & High \\
\hline No. of Obs. & 400 & 400 & 400 & 400 & 400 & 400 & 400 & 400 & 400 & 400 & 400 & 400 & 400 & 400 & 400 & 400 & 400 & 400 & 400 & 400 & 400 & 400 & 400 & 400 \\
\hline Mean & 1,553 & 1,744 & 1,700 & 1,597 & 1,725 & 1,572 & 1,550 & 1,747 & 251 & 274 & 284 & 241 & 279 & 246 & 246 & 280 & 140 & 154 & 152 & 142 & 155 & 139 & 144 & 151 \\
\hline Std.Dev & 388 & 412 & 355 & 455 & 441 & 363 & 379 & 419 & 80 & 89 & 83 & 84 & 92 & 75 & 77 & 90 & 36 & 40 & 40 & 37 & 44 & 31 & 38 & 39 \\
\hline Median & 1,498 & 1,642 & 1,636 & 1,490 & 1,643 & 1,518 & 1,491 & 1,681 & 255 & 279 & 282 & 240 & 281 & 254 & 250 & 281 & 129 & 145 & 144 & 131 & 143 & 131 & 135 & 141 \\
\hline $\begin{array}{l}\text { Diff. in } \\
\text { Means }\end{array}$ & $\begin{array}{r}190.9 \\
0\end{array}$ & $* * *$ & 102.30 & $* * *$ & 153.90 & $* * *$ & $\begin{array}{r}197.3 \\
0\end{array}$ & $* * *$ & 23.55 & $* * *$ & -42.28 & $* * *$ & $33.20^{-}$ & $* * *$ & 33.94 & $* * *$ & 13.64 & $* * *$ & -9.93 & $* * *$ & $16.76^{-}$ & $* * *$ & 7.07 & $* * *$ \\
\hline \multicolumn{25}{|c|}{ Panel B. U.S. Establishment Birth Rate } \\
\hline & \multicolumn{8}{|c|}{ U.S. Establishment Births for Firm Size 1-4 } & \multicolumn{8}{|c|}{ U.S. Establishment Rate of Change for Firm Size 5-9 } & \multicolumn{8}{|c|}{ U.S. Establishment Rate of Change for Firm Size 10-19 } \\
\hline & \multicolumn{2}{|c|}{$\begin{array}{l}\text { Homestead } \\
\text { Exemption }\end{array}$} & \multicolumn{2}{|c|}{$\begin{array}{c}\text { Number of } \\
\text { business } \\
\text { incubators per } 1 \\
\text { million people }\end{array}$} & \multicolumn{2}{|c|}{$\begin{array}{c}\text { Academic } \\
\text { science and } \\
\text { engineering } \\
\text { R\&D per } \$ 1,000 \\
\text { of GDP }\end{array}$} & \multicolumn{2}{|c|}{\begin{tabular}{|c} 
Number of \\
SBIR (Small \\
Business \\
Innovation \\
Research awards \\
per 1 million \\
people \\
\end{tabular}} & \multicolumn{2}{|c|}{$\begin{array}{l}\text { Homestead } \\
\text { Exemption }\end{array}$} & $\begin{array}{r}\text { Numl } \\
\text { busi } \\
\text { incubato } \\
\text { million }\end{array}$ & $\begin{array}{l}\text { ef of } \\
\text { ess } \\
\text { per } 1 \\
\text { eople }\end{array}$ & $\begin{array}{r}\text { Acac } \\
\text { scien } \\
\text { engin } \\
\text { R\&I } \\
\$ 1,000\end{array}$ & $\begin{array}{l}\text { emic } \\
\text { e and } \\
\text { eering } \\
\text { per } \\
\text { of GDP }\end{array}$ & $\begin{array}{r}\text { Num } \\
\text { SBIR } \\
\text { Bus } \\
\text { Inno } \\
\text { Rese } \\
\text { award } \\
\text { million } \\
\end{array}$ & $\begin{array}{l}\text { er of } \\
\text { Small } \\
\text { ness } \\
\text { ation } \\
\text { arch } \\
\text { per } 1 \\
\text { people } \\
\end{array}$ & $\begin{array}{l}\text { Hom } \\
\text { Exen }\end{array}$ & $\begin{array}{l}\text { stead } \\
\text { ption }\end{array}$ & $\begin{array}{r}\text { Numb } \\
\text { busi } \\
\text { incubato } \\
\text { million }\end{array}$ & $\begin{array}{l}\text { er of } \\
\text { less } \\
\text { s per } 1 \\
\text { people }\end{array}$ & $\begin{array}{r}\text { Aca } \\
\text { scien } \\
\text { engir } \\
\text { R\& } \\
\$ 1,000\end{array}$ & $\begin{array}{l}\text { emic } \\
\text { e and } \\
\text { ering } \\
\text { per } \\
\text { f GDP }\end{array}$ & $\begin{array}{r}\text { Num } \\
\text { SBIR } \\
\text { Bus } \\
\text { Inno } \\
\text { Researc } \\
\text { per 1 } \\
\text { pe }\end{array}$ & $\begin{array}{l}\text { of } \\
\text { Small } \\
\text { ess } \\
\text { tion } \\
\text { awards } \\
\text { illion } \\
\text { le } \\
\end{array}$ \\
\hline & Low & High & Low & High & Low & High & Low & High & Low & High & Low & High & Low & High & Low & High & Low & High & Low & High & Low & High & Low & High \\
\hline No. of Obs. & 400 & 400 & 400 & 400 & 400 & 400 & 400 & 400 & 400 & 400 & 400 & 400 & 400 & 400 & 400 & 400 & 400 & 400 & 400 & 400 & 400 & 400 & 400 & 400 \\
\hline Mean & $\begin{array}{c}16.04 \\
\%\end{array}$ & $\begin{array}{c}16.74 \\
\%\end{array}$ & $\begin{array}{c}16.99 \\
\%\end{array}$ & $\begin{array}{c}15.79 \\
\%\end{array}$ & $\begin{array}{c}16.31 \\
\%\end{array}$ & $\begin{array}{c}16.47 \\
\%\end{array}$ & $\begin{array}{c}15.88 \\
\%\end{array}$ & $\begin{array}{c}16.90 \\
\%\end{array}$ & $\begin{array}{c}6.68 \\
\%\end{array}$ & $\begin{array}{c}7.00 \\
\%\end{array}$ & $7.48 \%$ & $\begin{array}{c}6.20 \\
\%\end{array}$ & $\begin{array}{c}6.93 \\
\%\end{array}$ & $\begin{array}{c}6.75 \\
\%\end{array}$ & $\begin{array}{c}6.58 \\
\%\end{array}$ & $\begin{array}{c}7.10 \\
\%\end{array}$ & $\begin{array}{c}5.95 \\
\%\end{array}$ & $\begin{array}{c}6.28 \\
\%\end{array}$ & $6.42 \%$ & $\begin{array}{c}5.81 \\
\%\end{array}$ & $\begin{array}{c}6.19 \\
\%\end{array}$ & $\begin{array}{c}6.05 \\
\%\end{array}$ & $6.13 \%$ & $\begin{array}{c}6.11 \\
\%\end{array}$ \\
\hline Std.Dev & $\begin{array}{c}2.45 \\
\%\end{array}$ & $\begin{array}{c}3.09 \\
\%\end{array}$ & $2.91 \%$ & $\begin{array}{c}2.57 \\
\%\end{array}$ & $3.13 \%$ & $\begin{array}{c}2.45 \\
\%\end{array}$ & $\begin{array}{c}2.67 \\
\%\end{array}$ & $2.85 \%$ & $\begin{array}{c}1.96 \\
\%\end{array}$ & $\begin{array}{c}2.34 \\
\%\end{array}$ & $2.19 \%$ & $\begin{array}{c}1.93 \\
\%\end{array}$ & $\begin{array}{c}2.27 \\
\%\end{array}$ & $\begin{array}{c}2.04 \\
\%\end{array}$ & $\begin{array}{l}2.00 \\
\%\end{array}$ & $\begin{array}{c}2.29 \\
\%\end{array}$ & $\begin{array}{c}1.36 \\
\%\end{array}$ & $\begin{array}{c}1.79 \\
\%\end{array}$ & $1.75 \%$ & $\begin{array}{c}1.36 \\
\%\end{array}$ & $\begin{array}{c}1.74 \\
\%\end{array}$ & $\begin{array}{c}1.43 \\
\%\end{array}$ & $1.59 \%$ & $\begin{array}{c}1.61 \\
\%\end{array}$ \\
\hline Median & $\begin{array}{c}15.77 \\
\%\end{array}$ & $\begin{array}{c}16.14 \\
\%\end{array}$ & $\begin{array}{c}16.48 \\
\%\end{array}$ & $\begin{array}{c}15.46 \\
\%\end{array}$ & $\begin{array}{c}15.77 \\
\%\end{array}$ & $\begin{array}{c}16.23 \\
\%\end{array}$ & $\begin{array}{c}15.45 \\
\%\end{array}$ & $\begin{array}{c}16.42 \\
\%\end{array}$ & $\begin{array}{c}6.80 \\
\%\end{array}$ & $\begin{array}{c}6.95 \\
\%\end{array}$ & $7.41 \%$ & $\begin{array}{c}6.23 \\
\%\end{array}$ & $\begin{array}{c}6.93 \\
\%\end{array}$ & $\begin{array}{c}6.82 \\
\%\end{array}$ & $\begin{array}{c}6.72 \\
\%\end{array}$ & $\begin{array}{c}7.09 \\
\%\end{array}$ & $\begin{array}{c}5.69 \\
\%\end{array}$ & $\begin{array}{l}5.87 \\
\%\end{array}$ & $6.02 \%$ & $\begin{array}{c}5.59 \\
\%\end{array}$ & $\begin{array}{c}5.71 \\
\%\end{array}$ & $\begin{array}{l}5.79 \\
\%\end{array}$ & $5.87 \%$ & $\begin{array}{l}5.67 \\
\%\end{array}$ \\
\hline $\begin{array}{l}\text { Diff. in } \\
\text { Means }\end{array}$ & $\begin{array}{r}0.71 \\
\%\end{array}$ & $* * *$ & $-1.20 \%$ & $* * *$ & $0.16 \%$ & & $\begin{array}{r}1.02 \\
\%\end{array}$ & $* * *$ & $\begin{array}{r}0.33 \\
\%\end{array}$ & $* *$ & $-1.27 \%$ & $* * *$ & $\begin{array}{r}0.18 \\
\%\end{array}$ & & $\begin{array}{r}0.53 \\
\%\end{array}$ & $* * *$ & $\begin{array}{r}0.33 \\
\%\end{array}$ & $* * *$ & $-0.61 \%$ & $* * *$ & $\begin{array}{r}0.14 \\
\%\end{array}$ & & $-0.02 \%$ & \\
\hline
\end{tabular}




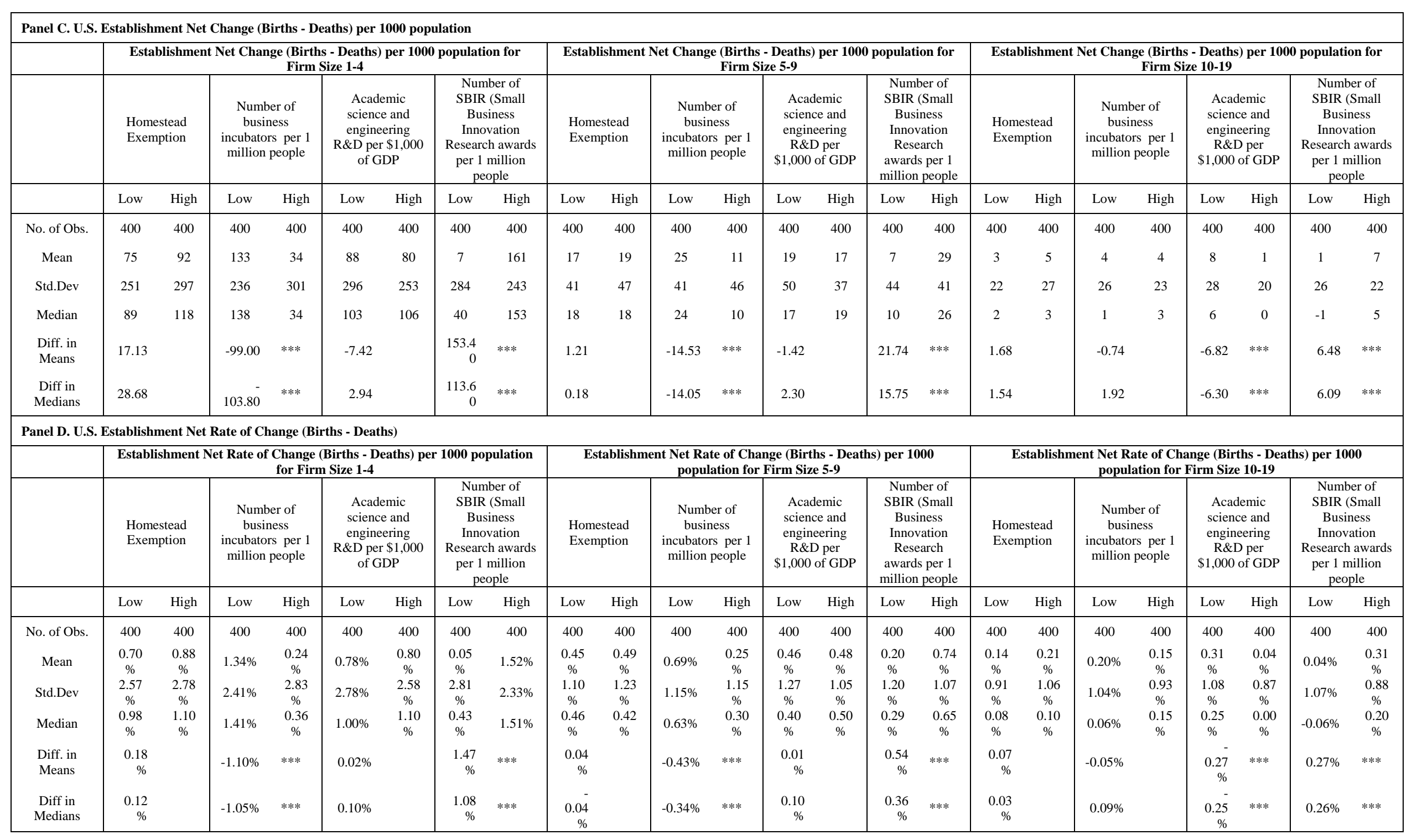




\begin{tabular}{|c|c|c|c|c|c|c|c|c|c|c|c|c|c|c|c|c|c|c|c|c|c|c|c|c|}
\hline & \multicolumn{8}{|c|}{ Venture Capital Deals per 1 million people } & \multicolumn{8}{|c|}{ Venture Capital Dollars per 1,000 people } & \multicolumn{8}{|c|}{ Patents per 1,000 people } \\
\hline & \multicolumn{2}{|c|}{$\begin{array}{l}\text { Homestead } \\
\text { Exemption }\end{array}$} & \multicolumn{2}{|c|}{$\begin{array}{c}\text { Number of } \\
\text { business } \\
\text { incubators per } 1 \\
\text { million people }\end{array}$} & \multicolumn{2}{|c|}{$\begin{array}{c}\text { Academic } \\
\text { science and } \\
\text { engineering } \\
\text { R\&D per } \$ 1,000 \\
\text { of GDP }\end{array}$} & \multicolumn{2}{|c|}{$\begin{array}{c}\text { Number of } \\
\text { SBIR (Small } \\
\text { Business } \\
\text { Innovation } \\
\text { Research awards } \\
\text { per } 1 \text { million } \\
\text { people } \\
\end{array}$} & \multicolumn{2}{|c|}{$\begin{array}{l}\text { Homestead } \\
\text { Exemption }\end{array}$} & \multicolumn{2}{|c|}{$\begin{array}{c}\text { Number of } \\
\text { business } \\
\text { incubators per } 1 \\
\text { million people }\end{array}$} & \multicolumn{2}{|c|}{$\begin{array}{l}\text { Academic } \\
\text { science and } \\
\text { engineering } \\
\text { R\&D per } \\
\$ 1,000 \text { of GDP }\end{array}$} & \multicolumn{2}{|c|}{$\begin{array}{c}\text { Number of } \\
\text { SBIR (Small } \\
\text { Business } \\
\text { Innovation } \\
\text { Research } \\
\text { awards per } 1 \\
\text { million people } \\
\end{array}$} & \multicolumn{2}{|c|}{$\begin{array}{l}\text { Homestead } \\
\text { Exemption }\end{array}$} & \multicolumn{2}{|c|}{$\begin{array}{l}\text { Number of } \\
\text { business } \\
\text { incubators per } 1 \\
\text { million people }\end{array}$} & \multicolumn{2}{|c|}{$\begin{array}{l}\text { Academic } \\
\text { science and } \\
\text { engineering } \\
\text { R\&D per } \\
\$ 1,000 \text { of GDP }\end{array}$} & \multicolumn{2}{|c|}{$\begin{array}{c}\text { Number of } \\
\text { SBIR (Small } \\
\text { Business } \\
\text { Innovation } \\
\text { Research awards } \\
\text { per } 1 \text { million } \\
\text { people } \\
\end{array}$} \\
\hline & Low & High & Low & High & Low & High & Low & High & Low & High & Low & High & Low & High & Low & High & Low & High & Low & High & Low & High & Low & High \\
\hline No. of Obs. & 400 & 400 & 400 & 400 & 400 & 400 & 400 & 400 & 400 & 400 & 400 & 400 & 400 & 400 & 400 & 400 & 400 & 400 & 400 & 400 & 400 & 400 & 400 & 400 \\
\hline Mean & 6.67 & 9.74 & 9.76 & 6.65 & 4.51 & 11.90 & 4.68 & 11.73 & $\begin{array}{c}39,87 \\
8\end{array}$ & $\begin{array}{c}63,48 \\
9\end{array}$ & 67,824 & $\begin{array}{c}35,54 \\
3\end{array}$ & $\begin{array}{c}22,09 \\
8\end{array}$ & $\begin{array}{c}81,26 \\
9\end{array}$ & $\begin{array}{c}24,44 \\
6\end{array}$ & $\begin{array}{c}78,92 \\
1\end{array}$ & 0.21 & 0.28 & 0.25 & 0.24 & 0.22 & 0.27 & 0.18 & 0.31 \\
\hline Std.Dev & 6.20 & 15.86 & 13.20 & 10.76 & 6.18 & 15.14 & 6.71 & 15.00 & $\begin{array}{c}58,28 \\
6\end{array}$ & $\begin{array}{c}147,9 \\
02\end{array}$ & $\begin{array}{c}138,97 \\
9\end{array}$ & $\begin{array}{c}75,59 \\
3\end{array}$ & $\begin{array}{c}46,59 \\
4\end{array}$ & $\begin{array}{c}147,0 \\
57\end{array}$ & $\begin{array}{c}44,08 \\
5\end{array}$ & $\begin{array}{c}148,7 \\
31\end{array}$ & 0.12 & 0.23 & 0.16 & 0.22 & 0.23 & 0.14 & 0.14 & 0.21 \\
\hline Median & 4.55 & 3.43 & 5.83 & 3.09 & 2.47 & 7.09 & 2.63 & 7.36 & $\begin{array}{c}20,97 \\
9\end{array}$ & $\begin{array}{c}13,48 \\
1\end{array}$ & 28,550 & $\begin{array}{c}10,78 \\
7\end{array}$ & 6,868 & $\begin{array}{c}35,95 \\
4\end{array}$ & 9,390 & $\begin{array}{c}34,35 \\
6\end{array}$ & 0.19 & 0.21 & 0.22 & 0.16 & 0.13 & 0.25 & 0.14 & 0.28 \\
\hline $\begin{array}{l}\text { Diff. in } \\
\text { Means }\end{array}$ & 3.07 & *** & -3.10 & $* * *$ & 7.40 & $* * *$ & 7.04 & $* * *$ & $\begin{array}{r}23,61 \\
1\end{array}$ & $* * *$ & 32,282 & $* * *$ & $\begin{array}{r}59,17 \\
1\end{array}$ & $* * *$ & $\begin{array}{r}54,47 \\
5\end{array}$ & $* * *$ & 0.07 & $* * *$ & -0.02 & & 0.05 & $* * *$ & 0.14 & $* * *$ \\
\hline $\begin{array}{l}\text { Diff in } \\
\text { Medians }\end{array}$ & -1.12 & $* *$ & -2.74 & $* * *$ & 4.62 & $* * *$ & 4.72 & $* * *$ & 7,498 & ** & 17,764 & $* * *$ & $\begin{array}{r}29,08 \\
6\end{array}$ & $* * *$ & $\begin{array}{r}24,96 \\
6\end{array}$ & $* * *$ & 0.02 & $* * *$ & -0.07 & $* * *$ & 0.12 & $* * *$ & 0.14 & $* * *$ \\
\hline
\end{tabular}


Table 4. Correlation Matrix

\begin{tabular}{|c|c|c|c|c|c|c|c|c|c|c|c|c|c|c|c|c|c|c|c|c|}
\hline \multicolumn{21}{|c|}{ Table 4. Correlation Matrix } \\
\hline & & [1] & [2] & [3] & [4] & [5] & [6] & [7] & [8] & [9] & [10] & [11] & {$[12]$} & [13] & [14] & {$[15]$} & [16] & {$[17]$} & [18] & [19] \\
\hline [1] & Births 1-4 / Population & 1.00 & & & & & & & & & & & & & & & & & & \\
\hline [2] & Births 5-9 / Population & 0.48 & 1.00 & & & & & & & & & & & & & & & & & \\
\hline [3] & Births 10-19 / Population & 0.60 & 0.47 & 1.00 & & & & & & & & & & & & & & & & \\
\hline [4] & Births - Deaths 1-4 / Population & 0.62 & 0.39 & 0.49 & 1.00 & & & & & & & & & & & & & & & \\
\hline [5] & Births - Deaths 5-9 / Population & 0.43 & 0.41 & 0.45 & 0.82 & 1.00 & & & & & & & & & & & & & & \\
\hline [6] & Births - Deaths 10-19 / Population & 0.26 & 0.03 & 0.66 & 0.41 & 0.45 & 1.00 & & & & & & & & & & & & & \\
\hline [7] & VC Number / Population & 0.07 & 0.01 & -0.05 & 0.04 & 0.04 & -0.04 & 1.00 & & & & & & & & & & & & \\
\hline [8] & VC Dollar / Population & 0.06 & 0.06 & -0.03 & 0.05 & 0.06 & -0.06 & 0.91 & 1.00 & & & & & & & & & & & \\
\hline [9] & Patents / Population & 0.22 & 0.04 & 0.05 & 0.07 & 0.01 & 0.03 & 0.44 & 0.34 & 1.00 & & & & & & & & & & \\
\hline [10] & Lag GDP / Population & 0.13 & -0.22 & -0.08 & -0.08 & -0.08 & 0.02 & 0.28 & 0.22 & 0.25 & 1.00 & & & & & & & & & \\
\hline [11] & $\begin{array}{c}\text { Lag Size of Gov. Index, Combining } \\
\text { 1A/1B/1C }\end{array}$ & 0.17 & 0.16 & 0.18 & 0.16 & 0.15 & 0.02 & 0.34 & 0.30 & 0.38 & 0.53 & 1.00 & & & & & & & & \\
\hline [12] & $\begin{array}{l}\text { Lag Takings and Dis. Tax Index, Combining } \\
\qquad 2 \mathrm{~A} / 2 \mathrm{~B} / 2 \mathrm{C}\end{array}$ & -0.07 & -0.27 & 0.01 & 0.01 & 0.06 & 0.15 & -0.08 & -0.09 & -0.07 & 0.41 & 0.29 & 1.00 & & & & & & & \\
\hline [13] & $\begin{array}{l}\text { Lag Labor Freedom Index, Combining } \\
\text { 3A/3B/3C }\end{array}$ & 0.04 & -0.21 & 0.14 & 0.00 & 0.04 & 0.15 & 0.07 & 0.03 & 0.03 & 0.24 & 0.38 & 0.52 & 1.00 & & & & & & \\
\hline [14] & Corporate - Income Taxes & -0.08 & -0.49 & -0.21 & -0.15 & -0.17 & 0.05 & -0.13 & -0.16 & 0.00 & 0.42 & -0.08 & 0.39 & 0.25 & 1.00 & & & & & \\
\hline [15] & Homestead_Exemption & 0.08 & 0.03 & 0.09 & -0.06 & -0.04 & -0.02 & 0.14 & 0.09 & 0.09 & \#\#\# & 0.04 & -0.06 & 0.11 & -0.04 & 1.00 & & & & \\
\hline [16] & Lag Education & 0.29 & 0.04 & 0.04 & 0.23 & 0.20 & -0.10 & 0.33 & 0.27 & 0.20 & 0.28 & 0.36 & -0.05 & 0.10 & 0.00 & -0.02 & 1.00 & & & \\
\hline [17] & $\begin{array}{c}\text { Lag Number of Business Incubators / } \\
\text { Population }\end{array}$ & -0.15 & -0.27 & -0.11 & -0.19 & -0.17 & 0.04 & -0.17 & -0.17 & -0.12 & 0.10 & -0.27 & 0.28 & 0.20 & 0.25 & -0.07 & -0.19 & 1.00 & & \\
\hline [18] & $\begin{array}{l}\text { Lag Number of Small Business Innovation } \\
\text { Research Awards / Population }\end{array}$ & 0.26 & 0.08 & 0.09 & 0.31 & 0.26 & 0.09 & 0.64 & 0.52 & 0.31 & 0.17 & 0.17 & -0.03 & 0.02 & -0.13 & 0.02 & 0.45 & -0.05 & 1.00 & \\
\hline [19] & Lag Personal Income Growth & 0.03 & -0.01 & 0.00 & 0.06 & 0.04 & 0.02 & 0.01 & 0.01 & 0.03 & 0.07 & 0.05 & 0.01 & -0.01 & 0.07 & -0.06 & 0.18 & -0.04 & 0.09 & 1.00 \\
\hline [20] & Lag Academic R\&D & -0.15 & -0.22 & -0.18 & -0.06 & -0.03 & -0.03 & 0.47 & 0.38 & 0.23 & 0.25 & 0.23 & 0.06 & 0.06 & 0.12 & -0.03 & 0.12 & -0.13 & 0.14 & 0.00 \\
\hline
\end{tabular}




\section{Table 5. Regression Analyses of Births}

This table presents fixed effect panel regressions of the determinants of new establishment births in each of the 50 states over the period $1995-2010$. Variables are as defined in Table 1. Year and state fixed effects are used for all Models. The dependent variables are as indicated in each Model. *, **, *** significant at the $1 \%$, $5 \%$ and $10 \%$ level of significance, respectively.

\begin{tabular}{|c|c|c|c|c|c|c|c|c|c|c|c|c|}
\hline & \multicolumn{2}{|c|}{$\begin{array}{c}\text { Model 1 } \\
\text { Full Sample } \\
\text { US Establishment Births } \\
\text { for Firm Size 1-4 / } \\
\text { Population }\end{array}$} & \multicolumn{2}{|c|}{$\begin{array}{c}\text { Model 2 } \\
\text { Full Sample } \\
\text { Excluding Outliers } \\
\text { US Establishment Births } \\
\text { for Firm Size 5-9 / } \\
\text { Population }\end{array}$} & \multicolumn{2}{|c|}{$\begin{array}{c}\text { Model 3 } \\
\text { Full Sample } \\
\text { US Establishment Births } \\
\text { for Firm Size 10-19 / } \\
\text { Population }\end{array}$} & \multicolumn{2}{|c|}{$\begin{array}{l}\text { Model 4 } \\
\text { Years } 2008 \text { - } 2010 \\
\text { US Establishment Births } \\
\text { for Firm Size 1-4 }\end{array}$} & \multicolumn{2}{|c|}{\begin{tabular}{|c} 
Model 5 \\
Years 2008 - 2010 \\
US Establishment Births \\
for Firm Size 5-9
\end{tabular}} & \multicolumn{2}{|c|}{$\begin{array}{c}\text { Model 6 } \\
\text { Years 2008 - } 2010 \\
\begin{array}{l}\text { US Establishment Births } \\
\text { for Firm Size 10-19 }\end{array}\end{array}$} \\
\hline & Coefficient & t-statistic & Coefficient & t-statistic & Coefficient & t-statistic & Coefficient & t-statistic & Coefficient & t-statistic & Coefficient & t-statistic \\
\hline Lag GDP / Population & 1.576 & 0.57 & 0.331 & 0.57 & 0.201 & 0.49 & 24.480 & $3.17^{* * *}$ & 2.469 & $1.87^{*}$ & -1.838 & $-1.79 *$ \\
\hline $\begin{array}{c}\text { Lag Size of Gov. } \\
\text { Index, Combining } \\
\text { 1A/1B/1C }\end{array}$ & -4.760 & -0.28 & -8.095 & $-2.24 * *$ & -1.523 & -0.60 & -30.212 & -0.75 & 14.718 & $2.15^{* *}$ & -9.074 & $-1.70 *$ \\
\hline $\begin{array}{c}\text { Lag Takings and Dis. } \\
\text { Tax Index, Combining } \\
\text { 2A/2B/2C }\end{array}$ & 35.713 & $2.68 * * *$ & -0.538 & -0.19 & 5.419 & $2.76^{* * *}$ & 9.187 & 0.26 & -5.568 & -0.93 & 0.985 & 0.21 \\
\hline $\begin{array}{c}\text { Lag Labor Freedom } \\
\text { Index, Combining } \\
\text { 3A/3B/3C }\end{array}$ & 196.821 & $6.89 * * *$ & 4.108 & 0.68 & 7.780 & $1.85^{*}$ & 144.419 & $2.16^{* *}$ & 27.513 & $2.41^{* *}$ & 27.631 & $3.1^{* * *}$ \\
\hline $\begin{array}{c}\text { Corporate - Income } \\
\text { Taxes }\end{array}$ & -16.262 & -0.05 & 24.406 & 0.33 & -6.105 & -0.12 & -972.378 & -1.10 & -52.817 & -0.35 & 20.344 & 0.17 \\
\hline $\begin{array}{l}\text { Lag Number of } \\
\text { Venture Capital Deals } \\
\text { / Population }(* 100)\end{array}$ & -0.558 & -0.68 & 0.248 & 1.44 & -0.062 & -0.51 & -0.569 & -0.17 & -0.175 & -0.31 & -0.073 & -0.16 \\
\hline $\begin{array}{l}\text { Lag Patents / } \\
\text { Population }\end{array}$ & 165.193 & $2.88^{* * *}$ & -16.224 & -1.34 & 8.023 & 0.95 & 249.307 & 0.79 & 9.542 & 0.18 & 1.276 & 0.03 \\
\hline Homestead Exemption & $-3.97 \mathrm{E}-04$ & $-3.79 * * *$ & $-4.01 \mathrm{E}-05$ & $-1.82 *$ & $-3.79 \mathrm{E}-05$ & $-2.46 * *$ & 5.89E-04 & 0.48 & $-6.09 \mathrm{E}-04$ & $-2.93 * * *$ & $-1.76 \mathrm{E}-04$ & -1.08 \\
\hline $\begin{array}{l}\text { Lag Education } \\
\text { Lag Number of }\end{array}$ & 0.650 & 0.30 & -0.159 & -0.35 & -0.244 & -0.78 & 4.927 & $2.55^{* *}$ & 0.577 & $1.75^{*}$ & -0.521 & $-2.03 * *$ \\
\hline $\begin{array}{l}\text { Business Incubators / } \\
\text { Population } \\
\text { Lag Number of Small }\end{array}$ & 9.977 & 0.83 & 4.805 & $1.91^{*}$ & 3.464 & $1.97 * *$ & -80.671 & $-2.61^{* *}$ & -7.086 & -1.34 & 14.820 & $3.60^{* * *}$ \\
\hline $\begin{array}{l}\text { Business Innovation } \\
\text { Research Awards / } \\
\text { Population }\end{array}$ & 0.627 & 1.41 & 0.106 & 1.13 & -0.106 & -1.61 & 3.691 & 0.92 & 0.971 & 1.41 & 0.630 & 1.17 \\
\hline $\begin{array}{l}\text { Lag Personal Income } \\
\text { Growth }\end{array}$ & 0.602 & 0.50 & -0.139 & -0.55 & 3.19E-04 & 0.00 & -20.949 & -1.23 & 6.327 & $2.18^{* *}$ & 6.639 & $2.93^{* * *}$ \\
\hline Lag Academic R\&D & 5.99E-05 & $2.91^{* * *}$ & $1.88 \mathrm{E}-05$ & $4.34^{* * *}$ & $7.270 \mathrm{E}-07$ & 0.24 & 2.71E-04 & 1.59 & 7.79E-05 & $2.68^{* * *}$ & $-2.754 \mathrm{E}-05$ & -1.22 \\
\hline Constant & -721.916 & $-3.61 * * *$ & 160.136 & $3.81^{* * *}$ & 19.147 & 0.65 & -642.967 & -1.24 & -131.620 & -1.49 & 5.288 & 0.08 \\
\hline $\begin{array}{c}\text { Year and State Fixed } \\
\text { Effects? }\end{array}$ & \multicolumn{2}{|c|}{ Yes } & \multicolumn{2}{|c|}{ Yes } & \multicolumn{2}{|c|}{ Yes } & \multicolumn{2}{|c|}{ Yes } & \multicolumn{2}{|c|}{ Yes } & \multicolumn{2}{|c|}{ Yes } \\
\hline $\begin{array}{l}\text { Number of } \\
\text { Observations }\end{array}$ & \multicolumn{2}{|c|}{750} & \multicolumn{2}{|c|}{750} & \multicolumn{2}{|c|}{750} & \multicolumn{2}{|c|}{150} & \multicolumn{2}{|c|}{150} & \multicolumn{2}{|c|}{150} \\
\hline Overall Adjusted $\mathrm{R}^{2}$ & \multicolumn{2}{|c|}{0.947} & \multicolumn{2}{|c|}{0.944} & \multicolumn{2}{|c|}{0.871} & \multicolumn{2}{|c|}{0.963} & \multicolumn{2}{|c|}{0.927} & \multicolumn{2}{|c|}{0.870} \\
\hline
\end{tabular}


Table 6. Regression Analyses of Births - Deaths

This table presents fixed effect panel regressions of the determinants net changes in establishments (births - deaths) in each of the 50 states over the period 1995-2010. Variables are as defined in Table 1. Year and state fixed effects are used for all Models. The dependent variables are as indicated in each Model. *, **, *** significant at the $1 \%, 5 \%$ and $10 \%$ level of significance, respectively.

\begin{tabular}{|c|c|c|c|c|c|c|c|c|c|c|c|c|}
\hline & \multicolumn{2}{|c|}{$\begin{array}{c}\text { Model } 7 \\
\text { Full Sample } \\
\text { US Establishment Births- } \\
\text { Deaths for Firm Size 1-4 }\end{array}$} & \multicolumn{2}{|c|}{$\begin{array}{c}\text { Model } 8 \\
\text { Full Sample } \\
\text { US Establishment Births- } \\
\text { Deaths for Firm Size 5-9 }\end{array}$} & \multicolumn{2}{|c|}{$\begin{array}{c}\text { Model } 9 \\
\text { Full Sample } \\
\text { US Establishment } \\
\text { Births-Deaths for Firm } \\
\text { Size 10-19 }\end{array}$} & \multicolumn{2}{|c|}{$\begin{array}{c}\text { Model } 10 \\
\text { Years } 2008 \text { - } 2010 \\
\text { US Establishment Births- } \\
\text { Deaths for Firm Size 1-4 }\end{array}$} & \multicolumn{2}{|c|}{$\begin{array}{c}\text { Model 11 } \\
\text { Years 2008 - } 2010 \\
\text { US Establishment } \\
\text { Births-Deaths for Firm } \\
\text { Size 5-9 }\end{array}$} & \multicolumn{2}{|c|}{$\begin{array}{c}\text { Model } 12 \\
\text { Years } 2008 \text { - } 2010 \\
\text { US Establishment } \\
\text { Births-Deaths for Firm } \\
\text { Size 10-19 }\end{array}$} \\
\hline & Coefficient & t-statistic & Coefficient & t-statistic & Coefficient & t-statistic & Coefficient & t-statistic & Coefficient & t-statistic & Coefficient & t-statistic \\
\hline Lag GDP / Population & 3.542 & 0.82 & 0.162 & 0.21 & -0.245 & -0.49 & 49.371 & $3.48^{* * *}$ & 6.035 & $2.51^{* *}$ & -1.185 & -0.78 \\
\hline $\begin{array}{l}\text { Lag Size of Gov. Index, } \\
\text { Combining } 1 \mathrm{~A} / 1 \mathrm{~B} / 1 \mathrm{C}\end{array}$ & -79.768 & $-2.99 * * *$ & -10.142 & $-2.12 * *$ & 1.016 & 0.33 & -100.149 & -1.36 & 5.038 & 0.40 & -5.435 & -0.69 \\
\hline $\begin{array}{c}\text { Lag Takings and Dis. } \\
\text { Tax Index, Combining } \\
2 \mathrm{~A} / 2 \mathrm{~B} / 2 \mathrm{C}\end{array}$ & -6.688 & -0.32 & -6.526 & $-1.75^{*}$ & 1.189 & 0.49 & -27.766 & -0.43 & -19.384 & $-1.77^{*}$ & -11.904 & $-1.72 *$ \\
\hline $\begin{array}{l}\text { Lag Labor Freedom } \\
\text { Index, Combining } \\
\text { 3A/3B/3C }\end{array}$ & 204.639 & $4.61^{* * *}$ & 16.167 & $2.03^{* *}$ & 9.206 & $1.79 *$ & 139.221 & 1.13 & 10.315 & 0.49 & 10.446 & 0.79 \\
\hline $\begin{array}{c}\text { Corporate - Income } \\
\text { Taxes }\end{array}$ & 11.586 & 0.02 & 28.897 & 0.29 & 96.997 & 1.53 & -1616.660 & -0.99 & 6.492 & 0.02 & 150.616 & 0.86 \\
\hline $\begin{array}{l}\text { Lag Number of Venture } \\
\text { Capital Deals / } \\
\text { Population }(* 100)\end{array}$ & -2.281 & $-1.79 *$ & -0.194 & -0.85 & -0.184 & -1.24 & -1.998 & -0.32 & -0.324 & -0.31 & -0.471 & -0.71 \\
\hline Lag Patents / Population & 281.378 & $3.16^{* * *}$ & 37.859 & $2.37 * *$ & 16.664 & 1.61 & -252.889 & -0.44 & -31.544 & -0.32 & -25.193 & -0.41 \\
\hline Homestead Exemption & $-5.93 E-04$ & $-3.64 * * *$ & $-1.17 \mathrm{E}-04$ & $-4.00 * * *$ & $-5.97 \mathrm{E}-05$ & $-3.15 * * *$ & $1.55 \mathrm{E}-03$ & 0.69 & $-1.59 \mathrm{E}-04$ & -0.42 & $1.12 \mathrm{E}-04$ & 0.47 \\
\hline Lag Education & 2.842 & 0.86 & -0.079 & -0.13 & -0.034 & -0.09 & 2.040 & 0.57 & -0.786 & -1.30 & -1.429 & $-3.75^{* * *}$ \\
\hline $\begin{array}{l}\text { Lag Number of Business } \\
\text { Incubators / Population }\end{array}$ & 67.459 & $3.63^{* * *}$ & 4.077 & 1.22 & 4.640 & $2.15^{* *}$ & -68.228 & -1.20 & -0.410 & -0.04 & 19.295 & $3.17 * *$ \\
\hline $\begin{array}{l}\text { Lag Number of Small } \\
\text { Business Innovation } \\
\text { Research Awards / } \\
\text { Population }\end{array}$ & 0.789 & 1.14 & -0.032 & -0.26 & -0.185 & $-2.3^{* *}$ & 12.074 & 1.63 & 1.823 & 1.45 & 1.234 & 1.55 \\
\hline $\begin{array}{l}\text { Lag Personal Income } \\
\text { Growth }\end{array}$ & $-9.07 \mathrm{E}-02$ & -0.05 & $-8.53 \mathrm{E}-02$ & -0.25 & 7.51E-02 & 0.35 & -61.976 & $-1.98^{*}$ & 11.026 & $2.08 * *$ & 5.303 & 1.58 \\
\hline Lag Academic R\&D & 4.81E-05 & 1.50 & 7.04E-06 & 1.23 & $-6.65 E-07$ & -0.18 & 9.32E-05 & 0.30 & 5.77E-05 & 1.09 & $-5.80 \mathrm{E}-05$ & $-1.73^{*}$ \\
\hline Constant & -1563.668 & $-5.035^{* * *}$ & -66.526 & -1.193 & -63.637 & $-1.766 *$ & -1850.976 & $-1.95^{*}$ & -177.973 & -1.10 & 66.972 & 0.66 \\
\hline $\begin{array}{c}\text { Year and State Fixed } \\
\text { Effects? }\end{array}$ & \multicolumn{2}{|c|}{ Yes } & \multicolumn{2}{|c|}{ Yes } & \multicolumn{2}{|c|}{ Yes } & \multicolumn{2}{|c|}{ Yes } & \multicolumn{2}{|c|}{ Yes } & \multicolumn{2}{|c|}{ Yes } \\
\hline $\begin{array}{c}\text { Number of Observations } \\
\text { Overall Adjusted } \mathrm{R}^{2}\end{array}$ & \multicolumn{2}{|c|}{$\begin{array}{c}750 \\
0711\end{array}$} & \multicolumn{2}{|c|}{$\begin{array}{c}750 \\
0.628\end{array}$} & \multicolumn{2}{|c|}{$\begin{array}{c}750 \\
0.517\end{array}$} & \multicolumn{2}{|c|}{$\begin{array}{c}150 \\
0.668\end{array}$} & \multicolumn{2}{|c|}{$\begin{array}{c}150 \\
0.588\end{array}$} & \multicolumn{2}{|c|}{$\begin{array}{c}150 \\
0.630\end{array}$} \\
\hline
\end{tabular}




\section{Table 7. Regression Analyses of Venture Capital Deals, Venture Capital Dollars, and Patents}

This table presents fixed effect panel regressions of the determinants of venture capital (VC) deals, dollars, and patents per population in firms in each of the 50 states over the period 1995-2010. Variables are as defined in Table 1. Year and state fixed effects are used for all Models. The dependent variables are as indicated in each Model. *, **, *** significant at the $1 \%$, 5\% and $10 \%$ level of significance, respectively.

\begin{tabular}{|c|c|c|c|c|c|c|c|c|c|c|c|c|}
\hline & \multicolumn{2}{|c|}{$\begin{array}{c}\text { Model } 13 \\
\text { Full Sample } \\
\text { VC Deals / Population }\end{array}$} & \multicolumn{2}{|c|}{$\begin{array}{c}\text { Model } 14 \\
\text { Full Sample } \\
\text { VC Dollars / Population }\end{array}$} & \multicolumn{2}{|c|}{$\begin{array}{c}\text { Model } 15 \\
\text { Full Sample } \\
\text { Patents / Population }\end{array}$} & \multicolumn{2}{|c|}{$\begin{array}{c}\text { Model } 16 \\
\text { Years } 2008 \text { - } 2010 \\
\text { VC Deals / Population }\end{array}$} & \multicolumn{2}{|c|}{$\begin{array}{c}\text { Model } 17 \\
\text { Years } 2008 \text { - } 2010 \\
\text { VC Dollars / Population }\end{array}$} & \multicolumn{2}{|c|}{$\begin{array}{c}\text { Model } 18 \\
\text { Years } 2008 \text { - } 2010 \\
\text { Patents / Population }\end{array}$} \\
\hline & Coefficient & t-statistic & Coefficient & t-statistic & Coefficient & t-statistic & Coefficient & t-statistic & Coefficient & t-statistic & Coefficient & t-statistic \\
\hline Lag GDP / Population & 0.036 & 0.29 & 215 & 0.11 & 0.006 & $3.21^{* * *}$ & -0.273 & -1.19 & -320.865 & -0.20 & 0.007 & $4.35^{* *}$ \\
\hline $\begin{array}{l}\text { Lag Size of Gov. Index, } \\
\text { Combining 1A/1B/1C }\end{array}$ & 0.397 & 0.50 & 9213 & 0.74 & -0.009 & -0.80 & -0.005 & 0.00 & -2869.036 & -0.38 & 0.002 & 0.21 \\
\hline $\begin{array}{l}\text { Lag Takings and Dis. Tax } \\
\text { Index, Combining 2A/2B/2C }\end{array}$ & -1.378 & $-2.29 * *$ & -13742 & -1.45 & 0.013 & 1.48 & 1.385 & 1.37 & 10412 & 1.50 & 0.002 & 0.32 \\
\hline $\begin{array}{l}\text { Lag Labor Freedom Index, } \\
\text { Combining 3A/3B/3C }\end{array}$ & 3.930 & $2.94^{* * *}$ & 49452 & $2.34 * *$ & -0.056 & $-3.01^{* * *}$ & 3.513 & $1.76^{*}$ & 18687 & 1.37 & -0.075 & $-4.41^{* * *}$ \\
\hline $\begin{array}{l}\text { Corporate - Income Taxes } \\
\text { Lag Number of Venture }\end{array}$ & 27.136 & $1.70^{*}$ & 254031 & 1.01 & $-1.858 \mathrm{E}-04$ & 0.00 & -17.296 & -0.69 & -44615 & -0.26 & -0.219 & -1.23 \\
\hline $\begin{array}{l}\text { Capital Deals / Population } \\
\qquad(* 100)\end{array}$ & & & & & $3.29 \mathrm{E}-04$ & 0.63 & & & & & $1.05 \mathrm{E}-03$ & $2.12 * *$ \\
\hline Lag Patents / Population & 5.535 & $2.12 * *$ & 74942 & $1.82 *$ & & & -13.313 & -1.48 & -2020 & -0.03 & & \\
\hline Homestead Exemption & $-3.13 E-06$ & -0.65 & -0.072 & -0.95 & $6.31 \mathrm{E}-08$ & 0.93 & $-4.08 \mathrm{E}-07$ & -0.01 & -0.130 & -0.56 & 1.32E-08 & 0.19 \\
\hline Lag Education & 0.027 & 0.28 & 430 & 0.28 & -0.006 & $-4.07 * * *$ & -0.096 & -1.48 & -333 & -0.75 & -0.001 & -1.19 \\
\hline $\begin{array}{l}\text { Lag Number of Business } \\
\text { Incubators / Population }\end{array}$ & 0.326 & 0.59 & 347 & 0.04 & 0.011 & 1.40 & 0.233 & 0.26 & -455 & -0.07 & 0.001 & 0.11 \\
\hline $\begin{array}{l}\text { Lag Number of Small } \\
\text { Business Innovation Research } \\
\text { Awards / Population }\end{array}$ & 0.057 & $2.81^{* * *}$ & 885 & $2.77^{* * *}$ & 0.000 & -1.01 & 0.661 & $6.17^{* * *}$ & 4596 & $6.25^{* * *}$ & 0.000 & 0.47 \\
\hline Lag Personal Income Growth & -0.057 & -1.04 & -503 & -0.59 & $-2.61 \mathrm{E}-04$ & -0.34 & 0.080 & 0.17 & -1196 & -0.37 & $-1.01 \mathrm{E}-04$ & -0.13 \\
\hline Lag Academic R\&D & $-2.840 \mathrm{E}-06$ & $-3.01 * * *$ & -0.042 & $-2.79 * * *$ & 2.049E-08 & 1.54 & $-9.560 \mathrm{E}-06$ & $-2.02 * *$ & -0.043 & -1.33 & $1.340 \mathrm{E}-08$ & 1.03 \\
\hline $\begin{array}{l}\text { US Establishment Births for } \\
\text { Firm Size 1-4 }\end{array}$ & 4.43E-04 & 0.24 & 18.108 & 0.62 & $4.970 \mathrm{E}-06$ & 0.19 & 4.53E-03 & 1.49 & 26.683 & 1.28 & $-3.443 \mathrm{E}-05$ & -1.49 \\
\hline $\begin{array}{l}\text { US Establishment Births for } \\
\text { Firm Size 5-9 }\end{array}$ & 1.43E-02 & $1.67 *$ & 160.247 & 1.19 & $-1.847 \mathrm{E}-04$ & -1.54 & $-1.20 \mathrm{E}-02$ & -0.72 & -145 & -1.27 & $-1.001 \mathrm{E}-04$ & -1.53 \\
\hline $\begin{array}{l}\text { US Establishment Births for } \\
\text { Firm Size 10-19 }\end{array}$ & 7.39E-03 & 0.58 & 169.330 & 0.84 & 1.179E-04 & 0.66 & $-2.08 \mathrm{E}-02$ & -1.27 & -219.415 & $-1.95^{*}$ & $-2.541 \mathrm{E}-04$ & -2.60 \\
\hline Constant & -23.276 & $-2.52^{* *}$ & -355678 & $-2.44^{* *}$ & 0.269 & $2.07 * *$ & -18.129 & -1.20 & -121638 & -1.18 & 0.482 & 3.93 \\
\hline Year and State Fixed Effects? & \multicolumn{2}{|c|}{ Yes } & \multicolumn{2}{|c|}{ Yes } & \multicolumn{2}{|c|}{ Yes } & \multicolumn{2}{|c|}{ Yes } & \multicolumn{2}{|c|}{ Yes } & \multicolumn{2}{|c|}{ Yes } \\
\hline Number of Observations & \multirow{2}{*}{\multicolumn{2}{|c|}{$\begin{array}{c}750 \\
0.847\end{array}$}} & \multirow{2}{*}{\multicolumn{2}{|c|}{$\begin{array}{c}750 \\
0.553\end{array}$}} & \multirow{2}{*}{\multicolumn{2}{|c|}{$\begin{array}{c}750 \\
0890\end{array}$}} & \multirow{2}{*}{\multicolumn{2}{|c|}{150}} & \multirow{2}{*}{\multicolumn{2}{|c|}{150}} & \multicolumn{2}{|c|}{150} \\
\hline Overall Adjusted $\mathrm{R}^{2}$ & & & & & & & & & & & 0.8 & \\
\hline
\end{tabular}

